Review

\title{
Current Understanding of Novel Coronavirus: Molecular Pathogenesis, Diagnosis, and Treatment Approaches
}

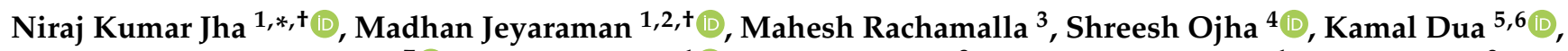 \\ Dinesh Kumar Chellappan ${ }^{7}{ }^{\circ}$, Sathish Muthu ${ }^{1}{ }^{\circ}$, Ankur Sharma ${ }^{8}$, Saurabh Kumar Jha ${ }^{1}$, Rashmi Jain ${ }^{9}$, \\ Naveen Jeyaraman ${ }^{10}$, Prajwal GS ${ }^{11}$, Rohit Satyam ${ }^{12}$, Fahad Khan $\left.{ }^{12}{ }^{(}\right)$, Pratibha Pandey ${ }^{12}{ }^{\circ}$, Nitin Verma ${ }^{13}{ }^{(0)}$, \\ Sandeep Kumar Singh ${ }^{14}{ }^{\oplus}$, Shubhadeep Roychoudhury ${ }^{15}{ }^{\circledR}$, Sunny Dholpuria ${ }^{8}$, Janne Ruokolainen ${ }^{16}$ and \\ Kavindra Kumar Kesari ${ }^{16, *(1)}$
}

check for

updates

Citation: Jha, N.K.; Jeyaraman, M.; Rachamalla, M.; Ojha, S.; Dua, K.; Chellappan, D.K.; Muthu, S.; Sharma, A.; Jha, S.K.; Jain, R.; et al. Current Understanding of Novel Coronavirus: Molecular Pathogenesis, Diagnosis, and Treatment Approaches. Immuno 2021, 1, 30-66. https://doi.org/ 10.3390/immuno1010004

Academic Editor: Toshihiko Torigoe

Received: 6 February 2021

Accepted: 23 March 2021

Published: 26 March 2021

Publisher's Note: MDPI stays neutral with regard to jurisdictional claims in published maps and institutional affiliations.

Copyright: (c) 2021 by the authors. Licensee MDPI, Basel, Switzerland. This article is an open access article distributed under the terms and conditions of the Creative Commons Attribution (CC BY) license (https:// creativecommons.org/licenses/by/ $4.0 /)$.
1 Department of Biotechnology, School of Engineering \& Technology (SET), Sharda University, Greater Noida 201310, India; madhanjeyaraman@gmail.com (M.J.); drsathishmuthu@gmail.com (S.M.); saurabh.jha@sharda.ac.in (S.K.J.)

2 Department of Orthopedics, School of Medical Sciences and Research, Sharda University, Greater Noida 201310, India

3 Department of Biology, University of Saskatchewan, 112 Science Place, Saskatoon, SK S7N 5E2, Canada; maheshgupta65@gmail.com or mar935@mail.Usask.ca

4 Department of Pharmacology and Therapeutics, College of Medicine and Health Sciences, United Arab Emirates University, Al Ain 17666, United Arab Emirates; shreeshojha@uaeu.ac.ae

5 Discipline of Pharmacy, Graduate School of Health, University of Technology Sydney, Sydney, NSW 2007, Australia; Kamal.Dua@uts.edu.au

6 School of Pharmaceutical Sciences, Shoolini University of Biotechnology and Management Sciences, Solan 173229, Himachal Pradesh, India

7 Department of Life Sciences, School of Pharmacy, International Medical University, Bukit Jalil, Kuala Lumpur 57000, Malaysia; dinesh_kumar@imu.edu.my

8 Department of Life Science, School of Basic Science \& Research (SBSR), Sharda University, Greater Noida 201310, India; ankur.sharma7@sharda.ac.in (A.S.); sunny.dholpuria@sharda.ac.in (S.D.)

9 School of Medical Sciences and Research, Sharda University, Greater Noida 201310, India; rashmijn05@gmail.com

10 Department of Orthopedics, Kasturba Medical College, Manipal 575001, Karnataka, India; naveenjeyaraman@yahoo.com

11 Department of Orthopedics, JJM Medical College, Davangere 577004, Karnataka, India; prajwalgs1894@gmail.com

12 Department of Biotechnology, Noida Institute of Engineering \& Technology, 19, Knowledge Park-II, Institutional Area, Greater Noida 201306, India; rohitsatyam102@gmail.com (R.S.);

fahadkhan.bio@niet.co.in (F.K.); pratibhapandey.bio@niet.co.in (P.P.)

13 School of Pharmacy, Chitkara University, Punjab 140401, Himachal Pradesh, India; nitin.verma@chitkarauniversity.edu.in

14 Indian Scientific Education and Technology Foundation, Lucknow 226002, India; sandeeps.bhu@gmail.com

15 Department of Life Science and Bioinformatics, Assam University, Silchar 788011, India; shubhadeep1@gmail.com

16 Department of Applied Physics, School of Science, Aalto University, 00076 Espoo, Finland; janne.ruokolainen@aalto.fi

* Correspondence: nirajkumarjha2011@gmail.com or niraj.jha@sharda.ac.in (N.K.J.); kavindra.kesari@aalto.fi (K.K.K.)

+ These authors contributed equally to this work.

Abstract: An outbreak of "Pneumonia of Unknown Etiology" occurred in Wuhan, China, in late December 2019. Later, the agent factor was identified and coined as severe acute respiratory syndrome coronavirus 2 (SARS-CoV-2), and the disease was named coronavirus disease 2019 (COVID-19). In a shorter period, this newly emergent infection brought the world to a standstill. On 11 March 2020, the WHO declared COVID-19 as a pandemic. Researchers across the globe have joined their hands to investigate SARS-CoV-2 in terms of pathogenicity, transmissibility, and deduce therapeutics to subjugate this infection. The researchers and scholars practicing different arts of medicine are on an extensive quest to come up with safer ways to curb the pathological implications of this viral infection. A huge number of clinical trials are underway from the branch of allopathy and 
naturopathy. Besides, a paradigm shift on cellular therapy and nano-medicine protocols has to be optimized for better clinical and functional outcomes of COVID-19-affected individuals. This article unveils a comprehensive review of the pathogenesis mode of spread, and various treatment modalities to combat COVID-19 disease.

Keywords: COVID-19; SARS-CoV-2; pathogenesis; natural products; vaccines; therapeutics; management; treatment

\section{Introduction}

The city of Wuhan in China witnessed an outbreak of pneumonia caused by a novel coronavirus in the late winter of December 2019, and with a rampant spread throughout China, it periled the world to emerge as a pandemic [1]. The etiological agent of the disease was originally called as 2019 novel coronavirus (2019-nCoV), but later it was named as severe acute respiratory syndrome coronavirus 2 (SARS-CoV-2), and the disease process as Coronavirus Disease-2019 (COVID-19) by the WHO [2]. Later, SARS-CoV-2 was declared an International Public Health Emergency by the WHO on 30th January 2020. As of 14th March 2021, the world has encountered 120 million confirmed cases and 2.6 million deaths reported among them (source: Worldometer, www.worldometers.info). The transmitting capacity of SARS-CoV-2 is beyond that of its ancestral SARS-CoV that caused an outbreak of SARS in 2003 [3]. The escalation in the number of confirmed COVID-19 cases forecasts the prevailing scenarios gloomily and warrants stringent preventive and control measures. The clinical spectrum and manifestations involve the respiratory system undergoing the major brunt of COVID-19 infection; however, damage to the cardiovascular system has been reported by some patients [4]. Some patients with existing cardiovascular diseases (CVDs) may have a higher risk of associated mortality. Therefore, it is equivalently important to understand the mechanisms and extent of damage to the cardiovascular system by SARS-CoV-2 infectivity and come up with an effective treatment for these patients while minimizing the associated mortality.

Currently, there is no definite antiviral therapy developed for treating SARS-CoV-2 infection. The mainstay of treatment is rendering supportive care, as per the presenting complaints of the patient. Even treating with a combination of recombinant Interferon (IFN) and Ribavirin has been reported to show limited response against SARS-CoV-2 infection [5,6]. Following the episodes of SARS and MERS epidemics, persistent efforts have been made in streamlining newer antiviral agents to target the viral proteases, polymerases, MTases, and entry proteins respectively. However, none proved to be fruitful in terms of effectivity during the clinical trials [7-9]. With the flattening of the COVID-19 curve of infectivity, immunotherapies involving plasma and antibodies procured from convalescent patients have been proposed to address the present circumstances [10]. Besides, various vaccine strategies involving utilization of inactivated viruses, live-attenuated viruses, viral vector-based vaccines, subunit vaccines, recombinant proteins, and DNA vaccines have been evaluated in animals and are emerging as a preventable strategy [11,12]. Due to the lack of traditional licensed treatment or vaccine, the infection mandates implementation of infection control measures with establishing an early diagnosis, reporting, isolation, and rendering supportive treatments effectively. Individualized efforts by inculcating the healthy practice of hand hygiene, respiratory hygiene and cough etiquette, wearing well-fitted face masks, and avoiding crowded places will supplement for the same.

Various therapeutic strategies have been used to treat this viral infection, but there have been unsuccessful reports recorded so far. However, natural products including plant-derived compounds and drugs can be a potential therapeutic approach to combat its growth and spreading capacity in the future. In this review, we have discussed the various pathological aspects including synthesis, maturation, infectivity, and diagnostic prospects 
of COVID-19. Additionally, we have also highlighted the recently used drugs and vaccines in combating SARS-CoV-2 infection.

\section{Classification, Origin, Primary Reservoirs, and Hosts of Coronavirus}

Adetailed outline of the source and transmission is important for developing preventive strategies for containing the spread of the infection. SARS-CoV-2 belongs to the order Nidovirales and family Cornaviridae. The family comprises two subfamilies, i.e., Torovirinae and Coronavirae. Subsequently, the members of the sub-family Coronaviridae are further divided into four genera: (i) alpha coronavirus, 229E, and NL63 are the human coronaviruses that are responsible for croup and the common cold, (ii) In comparison, SARS-CoV-2, MERS-CoV, HCoV-OC43, HCoV-HKU1, and SARS-CoV are classified as beta coronaviruses, (iii) Gamma coronavirus includes viruses of whales and birds, and (iv) Delta coronavirus comprises viruses isolated from birds and pigs [13]. These viruses infect a wide variety of host species, and diversity among these viruses leads to different pathological outcomes. The coronaviruses with pathological manifestations have been enumerated in Table 1 for a better understanding of the same.

Table 1. List of important pathogenic coronaviruses their host organisms, genera name, and associated clinical manifestations.

\begin{tabular}{|c|c|c|c|c|}
\hline S.No. & Name & Host Organism & Genera Name & Clinical Manifestations \\
\hline 1 & $\begin{array}{l}\text { Feline infectious } \\
\text { peritonitis virus }\end{array}$ & Cat & Alpha & $\begin{array}{l}\text { Vasculitis, fever, serositis, with or } \\
\text { without effusions }\end{array}$ \\
\hline 2 & $\begin{array}{l}\text { Camel alphacoronavirus } \\
\text { isolate camel/Riyadh }\end{array}$ & Camel & Alpha & Asymptomatic \\
\hline 3 & Canine CoV/TU336/F/2008 & Dog & Alpha & Diarrhea and mild clinical signs \\
\hline 4 & SeACoV-CH/GD-01 & Pig & Alpha & $\begin{array}{l}\text { Acute and severe diarrhea and } \\
\text { vomiting }\end{array}$ \\
\hline 5 & TGEV/PUR46-MAD & Pig & Alpha & Diarrhea \\
\hline 6 & PRCV/ISU-1 & Pig & Alpha & $\begin{array}{l}\text { Mild respiratory tract infections } \\
\text { (RTIs) }\end{array}$ \\
\hline 7 & PEDV /ZJU-G1-2013 & Pig & Alpha & Severe watery diarrhea \\
\hline 8 & Human CoV-NL63 & Human & Alpha & Mild RTIs \\
\hline 9 & Human CoV-229E & Human & Alpha & Mild RTIs \\
\hline 10 & MHV-A59 & Mouse & Beta & $\begin{array}{l}\text { Severe lung injuries and acute } \\
\text { pneumonia }\end{array}$ \\
\hline 11 & Equine CoV/Obihiro12-1 & Horse & Beta & Leucopenia, fever, and anorexia \\
\hline 12 & Bovine $\mathrm{CoV} / \mathrm{ENT}$ & Cow & Beta & Diarrhea \\
\hline 13 & MERS-CoV & Human & Beta & Severe acute respiratory syndrome \\
\hline 14 & SARS-CoV & Human & Beta & Severe acute respiratory syndrome \\
\hline 15 & Human CoV-OC43 & Human & Beta & Mild RTIs \\
\hline 16 & Human CoV-HKU1 & Human & Beta & Pneumonia \\
\hline 17 & IBV & Chicken & Gamma & Severe respiratory disease \\
\hline 18 & Beluga Whale CoV/SW1 & Whale & Gamma & $\begin{array}{l}\text { Terminal acute liver failure and } \\
\text { pulmonary disease }\end{array}$ \\
\hline 19 & Sparrow coronavirus HKU17 & Sparrow & Delta & Respiratory disease \\
\hline 20 & Bulbul coronavirus HKU11 & Bulbul & Delta & Respiratory disease \\
\hline
\end{tabular}

SARS-CoV-2 belongs to the beta coronavirus family as that of extremely pathogenic viruses such as SARS-CoV and MERS-CoV. It is a positive-sense single-stranded RNA 
(+ssRNA) and an enveloped virus. SARS-CoV-2 is regarded as a novel beta coronavirus infecting humans [14]. Indications have been received from the phylogenetic analysis of the SARS-CoV-2 genome suggesting its close relation (with $88 \%$ identity) to two coronaviruses that were bat-derived, SARS-like, and were collected in eastern China in 2018 (bat-SLCoVZC45 and bat-SL-CoVZXC21). However, it is genetically different from SARS-CoV (approximately 79\% similarity) and MERS-CoV [14]. A further study conducted using the genome sequences of SARS-CoV, RaTG13, and SARS-CoV-2 revealed that there is a better correlation between the virus and a bat coronavirus, BatCoV RaTG13, that had been previously detected in Yunnan province in Rhinolophus affinis, which resembles $96.2 \%$ of the overall identity of the genome sequence [15]. No evidence of recombination events was found during a study in the genome of SARS-CoV-2 from other viruses that originated from bats such as SARSr-CoVs, SARS-CoVs, and BatCoV RaTG13 [15]. When put together, these findings indicate the original host of the virus could be bats [14,15]. Albeit, there is a need to undertake relevant epidemiological studies to determine whether the transmission of the virus to humans is being facilitated by an intermediate host. It is unlikely that bats are the transmitting agents of the virus to humans due to various reasons [14]. (i) There are suggestions that despite having a relatively long branch sequence identity below $90 \%$ with bat-SL-CoVZXC21 and bat-SL-CoVZC45, they are not considered as the direct ancestors of SARS-CoV-2, (ii) In the Huanan Seafood Market, no bats were found being sold or purchased, but there were several non-aquatic animals (including mammals) that were up for purchase, (iii) Other animals have acted as intermediate hosts (camels and civets) in other coronaviruses where the natural reservoir is the bat. The instances include MERS$\mathrm{CoV}$ and SARS-CoV. Though, it is pertinent to mention here that bats do not always require an intermediary host for transmitting the viruses to humans. For instance, in Bangladesh, the Nipah virus was transmitted to humans through bats shedding into the sap of raw date palm [16].

Moreover, the initial focus of the researchers was on palm civets and raccoon dogs as the key reservoirs of the SARS-CoV infection. The research study reported positive results for the viral RNA detection from the samples isolated from civets only in the food market, suggesting civet palms as the secondary hosts [17]. In the year 2001, the samples isolated from healthy individuals were subjected to molecular assessment, and it showed the frequency rate of antibodies against the SARS coronavirus to be $2.5 \%$. This suggests that the circulation of the SARScoronavirus in humans might have started before the outbreak in 2003 [18]. Later on, the suggestion that bats can be a source of viral replication was suggested when it was found that Rhinolophus bats have anti-SARS-CoV antibodies [19]. The first emergence of MERS was in Saudi Arabia in 2012 [20]. The zoonotic source for MERS coronavirus was reported to be camels, and the identified etiological agent also belonged to betacoronavirus. During a study conducted recently, MERS coronavirus was also detected in Pipistrellus and Perimyotis bats, thereby proffering the bats to be the major transmitting medium and key host for the virus [21-23]. It was initially suggested by a group of researchers that snakes can be the possible hosts for the virus, but when the genomic similarity between SARS-like bat viruses and novel coronavirus was established, the statement that only bats can be the key reservoirs received support [24,25]. It was revealed from a detailed analysis of the homologous recombination that the development of the receptor binding spike glycoprotein of novel coronavirus occurs from a yet unknown Beta-CoV and a SARS-CoV (CoVZC45 or CoVZXC21) [26]. Further, more work is required for the eradication of the virus regarding the intermediate zoonotic source's identification that led to the transmission of the virus to humans. However, as predicted by Fan et al., there is also a possibility of another outbreak in a couple of years [27]. This was already expected for the current outbreak caused by SARS-CoV-2 (COVID-19), and it will also be contained as soon as earlier outbreaks. However, the key challenge is to plan and prepare ourselves to combat another zoonotic COVID-19 epidemic more effectively in the future. 


\section{Transmission Modes of Coronavirus}

Most of the initial cases of COVID-19 had been linked with the Huanan Seafood Market, thereby suggesting that the SARS-CoV-2 have been transmitted to humans from animals. The first mode of disease transmission and the plausible origination of SARS-CoV2 are not yet wellknown [28]. Initial cluster analysis of infections states that there was a common point of exposure for infected individuals: a seafood market in Wuhan, Hubei Province, China. The restaurants associated with this market are famous for providing diverse kinds of wild animals for consumption [29]. The role played by the Huanan Seafood Wholesale Market in spreading the disease is not clear yet. However, the Huanan South China Seafood market also trades in live animals, including bats, poultry, marmots, bats, and snakes [25]. This might be a point of zoonotic transmission [29]. Albeit, SARS-CoV-2 is alleged to have zoonotic origination with further human-to-human transmission, but the likelihood of its fecal-oral transmission mandates to rule out the same with additional epidemiological investigations [30]. Though evidence has been provided through a genomic study that the introduction of the virus into the Huanan Seafood Market took place from a yet unknown location, and from there on, it started spreading extremely quickly, but the human-to-human transmission might have started earlier [31]. In addition, it might transmit through direct contact as in other respiratory viruses, such as by shaking contaminated hands or exposure to contaminated surfaces (fomite transmission). Still, other potential routes of SARS-CoV-2 transmission such as blood transfusion, organ transplantation [32], and trans-placental and perinatal transmission need to be adduced more concretely.

The clusters of infected medical personnel and family members have confirmed the occurrence of person-to-person transmission [26]. The aforementioned transmission seemingly occurs among close contacts majorly through respiratory droplets produced upon coughing or sneezing by an infected person. The findings regarding the persistence of SARS-CoV-2 on surfaces for up to $96 \mathrm{~h}$ and other coronaviruses for up to 9 days account for a larger aspect of fomite transmission of infection $[33,34]$. However, the asymptomatic transmission of the infection remains controversial. An initial study that was published on 30 January 2020 reported on asymptomatic transmission, but it has been subsequently found that the researchers failed to direct interview the patient who certainly showed symptoms before disease transmission [35,36]. Another recent study, published on 21 February, also mentioned asymptomatic transmission; however, such studies can be limited due to errors in self-reported symptoms or unknowingly coming in contact with other fomites and cases [37]. The findings regarding the characteristics of the disease have been changing rapidly, and it is important to note that all are subjected to a selection bias. The average incubation period has been pegged at 5.2 days with a $95 \%$ confidence interval (95\% CI) of 4.1-7.0 days, while the other case studies have reported around 19 or 24 days respectively [38-40]. However, the definition of the case largely relies on a window of 14 days [41]. Estimation of the basic reproductive number $\left(R_{0}\right)$ has been done with varying interpretations and results. The average number of infections that can spread from a single infected individual in a fully susceptible population is measured by $R_{0}$ [42] $\mathrm{R}_{0}$ was found to be 2.7 for SARS from studies conducted on prior outbreaks and 2.4 for pandemic H1N1 influenza in 2009 [43,44]. Another study estimated the $\mathrm{R}_{0}$, was 2.2 (95\% CI: 1.4-3.9) [40]. However, on further analysis of other 12 available studies, the $R_{0}$ was found out to be 3.28 [45]. Though it must be taken into consideration that $R_{0}$ only represents an average value, the role of super-spreaders cannot be neglected, as they can be significantly responsible for an outbreak within large clusters, and they would otherwise not affect the value of $\mathrm{R}_{0}$ significantly [46]. Moreover, $\mathrm{R}_{0}$ might be unstable during the acute phase of the pandemic [42]. Notably, the comparison between epidemiological profiles of viral infections is enumerated in Figure 1. A study conducted on nine pregnant women who had developed COVID-19 during the later stages of their pregnancy suggested that the development of symptoms in pregnant persons is not any worse than that in nonpregnant persons, and there is no corroborating evidence for vertical transmission causing intrauterine infection [47]. A hospital-based study comprising 138 COVID-19 patients 
suggested that $41 \%$ of patients had a hospital-associated transmission of SARS-CoV-2 infection. Another study suggested a gradual increase in the percentage of cases among health care workers with due course of time [40]. The exposure to a higher concentration of virus due to prolonged contact in proximity is reflected from these case studies.

\begin{tabular}{|c|c|c|c|}
\hline Disease & MERS & SARS & COVID-19 \\
\hline \multirow[t]{2}{*}{$\begin{array}{c}\text { Disease Causing } \\
\text { Viruses }\end{array}$} & & & \\
\hline & MERS-CoV & SARS-CoV & SARS-CoV-2 \\
\hline $\begin{array}{l}\text { Basic Reproductive } \\
\text { Number }\left(R_{0}\right)\end{array}$ & $0.3-0.8$ & 3 & $2.0-2.5^{*}$ \\
\hline $\begin{array}{l}\text { Case Fatality Rate } \\
\text { (CFR) }\end{array}$ & $34.4 \%$ & $9.6-11 \%$ & $\sim 3.4 \%$ * \\
\hline Incubation Duration & 6 days & $2-7$ days & $4-14$ days * \\
\hline Hospitalization Rate & Most cases & Most cases & $\sim 19 \%$ * \\
\hline Community Attack Rate & $4-13 \%$ & $10-60 \%$ & $30-40 \%$ * \\
\hline Annual Infected (global) & 420 & 8098 (in 2003) & N/A (ongoing) \\
\hline
\end{tabular}

Figure 1. Epidemiological comparison of respiratory viral infections. $\left(^{*}\right)$ denotes the data obtained to date. The given percentage values are not fixed as they might change with time.

\section{Genome Structure and Life Cycle}

The incorporation of three major structural proteins defines the complex structure of the virus. The three proteins accounting for its structure are nucleocapsid protein $\mathrm{N}$ that is internally phosphorylated; glycoprotein S, representing the spike; and glycoprotein $\mathrm{M}$, which is an unusual transmembrane protein [48]. The bulky spike, which is found in the viral envelope with peplomers ranging between $15 \mathrm{~nm}$ to $20 \mathrm{~nm}$ and is represented by the glycoprotein $\mathrm{S}$ of 200K [49]. Moreover, the minor transmembrane protein E is also present in the structural region. An envelope protein that performs both the functions of hemagglutination and esterase (HE) is found in several species of coronaviruses [50]. Possessing a genome size of $30 \mathrm{~kb}$, these are single-stranded RNA viruses with a positivesense RNA [51]. While the 5' end is capped, the $3^{\prime}$ terminus is reportedly infectious and is polyadenylated. The expression of individual genes takes place through a complicated process, due to its bigger size, where at the $5^{\prime}$ end sequence, the release of the sets of nested mRNAs occurs. Extensive rearrangements facilitate the recombination of heterologous RNA. The leader RNA, which contains 65 to 98 nucleotides in an untranslated (UTR) sequence, occupies the $5^{\prime}$ end of the genome along with the $5^{\prime}$ end of the remaining sub-genomic mRNAs. At the $3^{\prime}$ end of the genome, the poly-A tail incorporates and follows another UTR region comprising 200 to 500 nucleotides. These two UTR regions are accountable for regulating the RNA transcription and replication processes. The genome of the coronavirus contains 7 to 14 open reading frames (ORFs). The beginning portion of the genome has gene one, which is $20-22 \mathrm{~kb}$ in length, and spreads across two-thirds of the genome. There are two ORFs, i.e., $1 \mathrm{a}$ and $1 \mathrm{~b}$, present in this portion, and these ORFs overlap and collectively function as the viral RNA polymerase (Pol). In the genome in this 
series, four significant structural proteins are incorporated, i.e., $5^{\prime}-\mathrm{S}$ (spike)-E (envelope)$\mathrm{M}$ (membrane)-N (nucleocapsid)-3' (Figure 2) [52]. The structural proteins are the key player in the virion'sassembly and defining the viral infectivity. The homotrimers of $S$ proteins constitute the spikes on the viral surface and facilitate attachment to the host receptors $[53,54]$. There are three transmembrane domains in the $\mathrm{M}$ protein that play a key role in shaping the virions, promoting membrane curvature, and binding to the nucleocapsid $[55,56]$. The E protein takes part in the process of assembly and release of the virus along with its involvement in the viral pathogenesis $[57,58]$. The $\mathrm{N}$ protein has two domains with the potentiality of binding the virus RNA genomic material through different mechanisms. It has been reported that $\mathrm{N}$ protein can bind to nsp3 protein to tether the genome to the replicase-transcriptase complex (RTC) and packaging the encapsidated genome into virions, respectively [59-61]. This $\mathrm{N}$ protein has also been found as an antagonist of the interferon (IFN) and the viral encoded repressor of RNA interference to perquisite the process of viral replication [62]. Within these genes, there are various other ORFs coding for other non-structural proteins such as HE glycoprotein. Depending on the features of the gene order, method of expression, and nucleotide sequence, the marking of each gene in coronavirus is distinct, though all of them are conserved amongst the same serogroup. As other coronaviruses encode smaller ORFs in these regions, the SARS-CoV-2 differs from them in the $3^{\prime}$ region of the genome regarding the expression of 8 novel proteins that have been marked as accessory proteins, and these ORFs are presently investigated. Both the ORFs, i.e., $1 \mathrm{a}$ and $1 \mathrm{~b}$, are identically translated into two poly-proteins at the $\mathrm{N}$-terminus while there is no production of the C-terminal identical polyproteins due to frame-shifting. ORF- $1 \mathrm{~b}$ encodes for a multifunctional helicase protein and the viral RNAdependent RNA polymerase (RdRp). This protein holds the $5^{\prime}$ triphosphatase, NTPase, and dNTPase activities. While all the structural proteins are not essentially required for the process of viral replication, inactivation of the viral function results from the deletion of one or more structural proteins. ORF-3a has a structural protein as one of its products has a role in the viral biogenesis as it is O-glycosylated, possessing the capability to bind $\mathrm{S}, \mathrm{N}$, $\mathrm{M}$ glycoproteins together, and is triple-membrane spanning in nature [63].

Coronaviruses encode for Mpro (main protease), also known as 3CLpro, which is a chymotrypsin-like protease and has similarities with the 3C protease of picornaviruses [64]. Sixteen non-structural proteins (nsps) are produced due to the remaining polyprotein being further processed by this protease. Among the nsp 1-16, most of the nsps have been found to have a role in the replication of these viruses. However, the functionality of some nsps is yet to be understood. The known functions of the $16 \mathrm{nsps}$ have been summarized in Table 2. SARS-CoV species of coronavirus have the maximum presence of nsps. Nsp3 is one such nsp that has multiplefunctions and contains both protease and ADP-ribose 1" phosphatase activity [65]. The two proteins nsp7 and nsp8 formulate a cylindrical structure and play a crucial role in synthesizing RNA for coronavirus and single-strand RNA binding protein (nsp9), respectively [66].

The life cycle of these viruses is a multistep event. This includes five steps in the lifecycle of the virus within the host, i.e., attachment, penetration, biosynthesis, maturation, and release [59]. First, the viral S protein attaches to the Angiotensin-Converting Enzyme-2 (ACE2) receptor of the host, then it enters the host cells through membrane fusion or endocytosis. Following the entry, there is aproteolytic cleavage of the virus envelope resulting in the release of genomic RNA in the cytoplasm, and smaller RNAs (sub-genomic mRNAs) are made. The viral RNA enters intothe nucleus for replication once the viral contents enter the host cells. The viral mRNA is used in the biosynthesis procedure for producing viral proteins. The mRNAs further undergo translation procedures to produce several proteins $(S, M, N$, etc.), which are essentially required for viral assembly. The $S, E$, and $M$ proteins enter the ER and result in the formation of nucleoprotein complex by combining $\mathrm{N}$ protein and genomic RNA (+strand). It is the ER-Golgi apparatus compartment wherein the complete virus particle (proteins and genomic RNA assembly) is formed. Thereafter, the 
latest viral particles are made and set off through the formation of vesicles and exocytosis, i.e., maturation (Figure 2).

Table 2. Non-structural proteins (nsps) and associated functions.

\begin{tabular}{|c|c|c|c|}
\hline S.No. & Name & Associated Functions & References \\
\hline 1 & nsp1 & $\begin{array}{l}\text { Inhibits IFNsignaling and involves in cellular } \\
\text { mRNA degradation }\end{array}$ & {$[67,68]$} \\
\hline 2 & nsp2 & Unclear & {$[69,70]$} \\
\hline 3 & nsp3 & $\begin{array}{l}\text { Promotescytokine expression, PLP, polypeptides } \\
\text { cleaving and blocks hostinnate immune response }\end{array}$ & {$[71,72]$} \\
\hline 4 & nsp4 & $\begin{array}{l}\text { Involves in double-membrane vesicle (DMV) } \\
\text { formation }\end{array}$ & {$[73,74]$} \\
\hline 5 & nsp5 & $\begin{array}{c}\text { Inhibits IFNsignaling, acts as a chymotrypsin-like } \\
\text { protease (3CLpro), main protease (Mpro), and } \\
\text { cleaves polypeptides }\end{array}$ & [75-77] \\
\hline 6 & nsp6 & $\begin{array}{l}\text { Restricts DMV formation and autophagosome } \\
\text { expansion }\end{array}$ & {$[78,79]$} \\
\hline 7 & nsp7 & Acts as a cofactor with nsp 8 and nsp12 & {$[64,80]$} \\
\hline 8 & nsp8 & $\begin{array}{l}\text { Primase activity and also acts as a cofactor with nsp7 } \\
\text { and nsp12 }\end{array}$ & {$[66,80,81]$} \\
\hline 9 & nsp9 & Involves in dimerization and RNA binding & {$[82,83]$} \\
\hline 10 & nsp10 & acts as a scaffold protein for nsp14 and nsp16 & [84-87] \\
\hline 11 & nsp11 & Unclear & [88] \\
\hline 12 & nsp12 & Primer dependent RdRp & {$[66,89,90]$} \\
\hline 13 & nsp13 & $5^{\prime}$ triphosphatase and RNA helicase & [91-93] \\
\hline 14 & nsp14 & N7-Mtase and exoribonuclease & [94-97] \\
\hline 15 & nsp15 & $\begin{array}{l}\text { Acts as an endoribonuclease and evasion of } \\
\text { double-stranded RNA viruses (dsRNA) sensors }\end{array}$ & [98-100] \\
\hline 16 & nsp16 & $\begin{array}{l}\text { 2'-O-Mtase avoids MDA5 recognition and } \\
\text { negatively regulates innate immunity }\end{array}$ & {$[85,86,101]$} \\
\hline
\end{tabular}

Specific genes are present in all the coronaviruses in ORF1 downstream regions, which encode the proteins for nucleocapsid, viral replication, and spikes formation [102]. On the outer surface of the coronaviruses, there are glycoprotein spikes that facilitate the entry and attachment of the virus to the host cells. The virus can infect multiple hosts due to loose attachment of the receptor-binding domain (RBD) among the virus $[103,104]$. Other coronaviruses recognize carbohydrates or aminopeptidases as the key receptor for entry into human cells, while SARS-CoV and MERS-CoV recognize exopeptidases [105]. Cellular proteases determine the entry mechanism of a coronavirus which includes cathepsins and transmembrane protease serine 2 (TMPRSS2) and human airway trypsin-like protease (HAT), that split the spike protein and establish further penetration changes $[106,107]$. As a key receptor, MERS coronavirus employs dipeptidyl peptidase 4 (DPP4), whileACE2 is required as a key receptor by SARScoronavirus and HCoV-NL63 [101,103]. A typical coronavirus structure with spike protein is possessed by SARS-CoV-2, and it expresses nucleoproteins, polyproteins, and membrane proteins such as papain-like protease, helicase, RNA polymerase, glycoprotein, 3-chymotrypsin-like protease, and accessory proteins [15,108]. To maintain the van der Waals forces, the SARS-CoV-2 spike protein comprisesa 3-D structure in the RBD region [109]. The critical lysine 31 residue on the human ACE2 receptor recognizes the 394 glutamine residue present in the SARS-CoV-2 RBD region [110]. The 
complete mechanism of SARS-CoV-2 pathogenicity, from attachment to replication, has been elaborated in Figures 2 and 3.

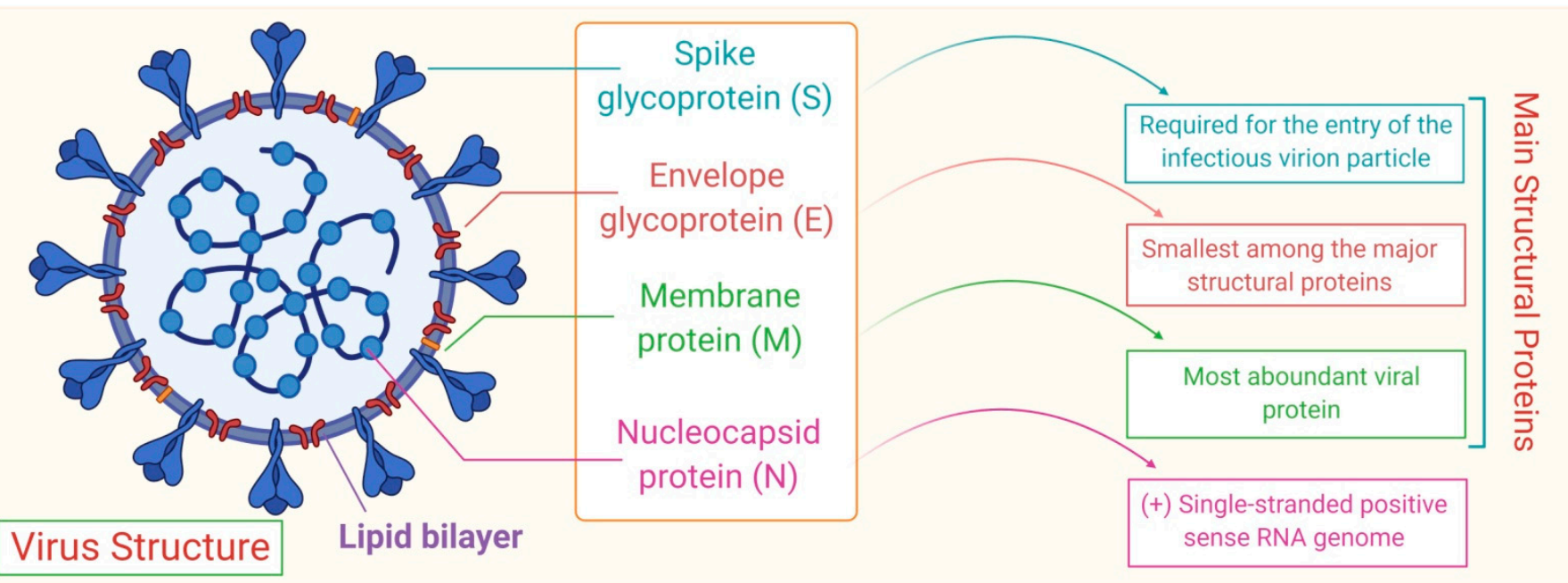

\section{Contaminations}

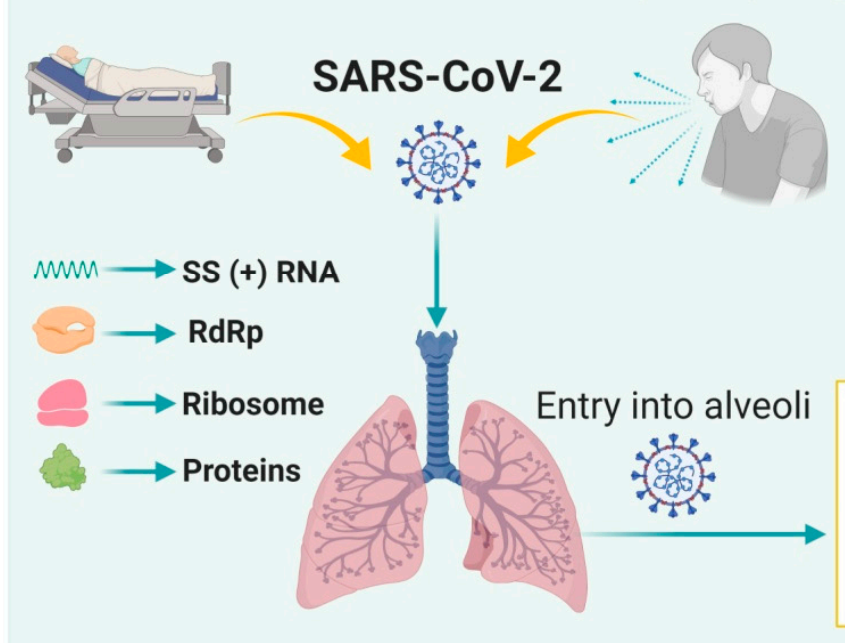

Life Cycle of SARS-CoV-2

\section{Respiratory droplets}

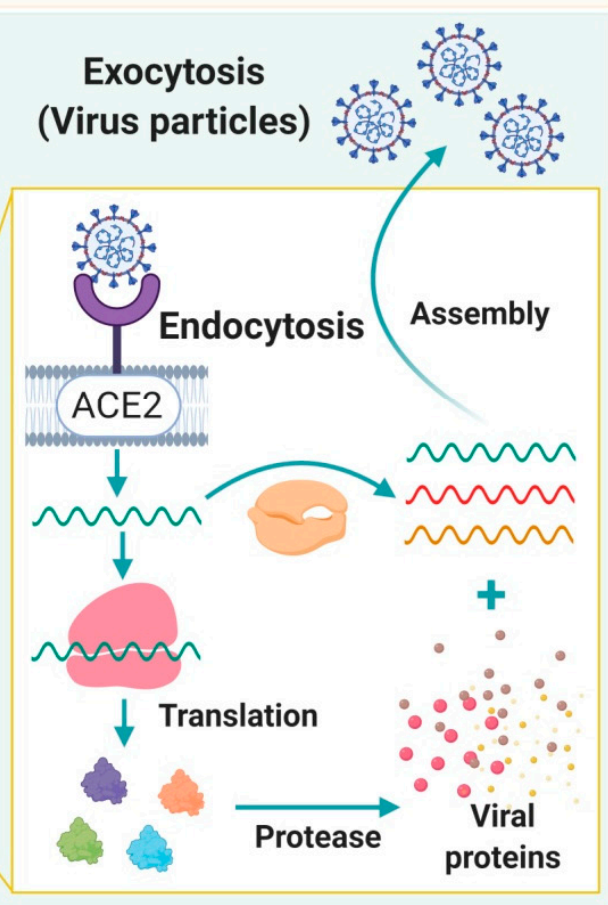

Figure 2. Structure and life cycle of SARS-CoV-2. The life cycle of SARS-CoV-2 is multistep event such as, binding of SARS-CoV-2-ACE2 receptor, proteolytic cleavage and fusion, release of viral RNA and uncoating of nucleoprotein, process of transcription(forming several mRNA transcripts including $\mathrm{S}, 3 \mathrm{a}, 3 \mathrm{~b}, \mathrm{E}, \mathrm{M}, 3,7 \mathrm{a}, 7 \mathrm{~b}, 8$, and N), replication and packaging of RNA, process of translation, assembly and procedure of budding, exocytosis, and finally, the release of virus takes place. 


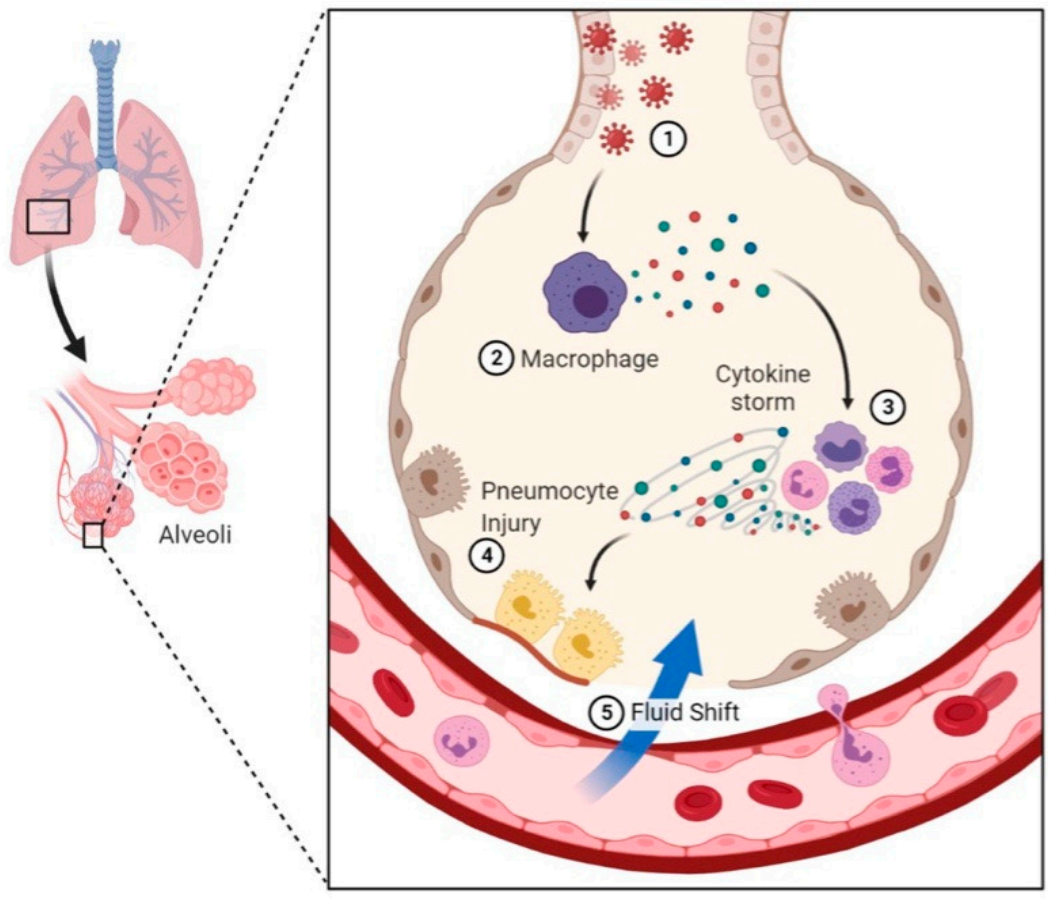

Pathophysiology of COVID-19

(1) Viral Entry

ACE-2 \& TMPRSS-2 Receptors

(2) Macrophage Activation

CD-8+T cells, Neutrophils, Lymphocytes

(3) Pro-inflammatory Cascade

IL-6, IL-10, IL-2, IL-13, TNF-a, IFN-y, VEGF, ROS, Proteases

(4) Acute Lung Injury

Alveolar oedema, Tachycardia, Tachypnoea, Hypotension

(5) Respiratory Failure

Acute Respiratory Distress Syndrome,

Systemic Inflammatory Response Syndrome,

Multi-Organ Dysfunction Syndrome

Figure 3. Molecular pathomechanisms of COVID-19.

\section{Risk Factors of Coronavirus}

Most incidences of SARS-CoV-2 infection are largely observed in adult male patients wherein the patient's median age was between 34 years and 59 years [37,38,111,112]. People suffering from chronic comorbidities like cerebrovascular diseases, cardiovascular ailments, and diabetes are more likely to be infected by the SARS-CoV-2 [113]. In adults 60 years and above, there has been the highest proportion of severe cases along with individuals with existing comorbidities such as cerebrovascular diseases, cardiovascular ailments, and diabetes [37,111]. Co-infections caused by fungi and bacteria may also be associated with severe manifestations [113]. Interestingly, fewer cases of SARS-CoV-2 infection have been reported among children less than 15 years of age [37,38,111,112]. As per a study published on 29th January and conducted in Wuhan on 425 COVID-19 patients, no cases were reported in children under the age of 15 years $[40,114]$. However, as of March 14th, 2021 according to the American Academy of Pediatrics, the USA alone hosts 3,231,836 pediatric COVID-19 cases, and these cases contribute $13.2 \%(3,231,836 / 24,487,634)$ of all cases. Overall, there are 4294 cases per every 100,000 children in the entire USA population (data retrieved from https:/ / services.aap.org/en/pages/2019-novel-coronavirus-covid-19 -infections/children-and-covid-19-state-level-data-report/, accessed on 14 March 2021).

At a glance, most infected patients showed mild symptoms without fever or pneumonia, having a good prognosis [115]. Notably, a study discovered that a child was asymptomatic despite suffering from radiological ground-glass lung opacities [26]. In a nutshell, children can be less likely to get infected, or even if they are infected, they exhibit milder manifestations as compared to adults. It is more likely that the parents or guardians of such children might not seek treatment, which can lead to underestimation of the instances of the disease in this age group.

\section{The Clinical Manifestations of COVID-19}

Patients infected with SARS-CoV-2 exhibit clinical manifestations ranging from nonspecific mild symptoms to severe pneumonia and damage of organ functions. Most common symptoms are cough (59.4-81.8\%), dyspnea (3.2-55.0\%), fever (77.4-98.6\%), fatigue (38.1-69.6\%), sputum production (28.2-56.5\%), myalgia (11.1-34.8\%), and headache 
$(6.5-33.9 \%)[109,116]$. Other lesser common symptoms include chest pain, hemoptysis, rhinorrhea, nausea, vomiting, sore throat, diarrhea, and conjunctive congestion. Though according to one study, out of the 140 confirmed COVID-19 patients, $39.6 \%$ of individuals exhibited gastrointestinal symptoms [117], and 10.1\% of patients infected with COVID-19 exhibited gastrointestinal discomfort at its onset [111]. Though many patients developed a fever after hospitalization when they did not have any fever at the onset of the infection [116], and several patients with severe infection did not have a fever at all. Several clinical manifestations such as dry cough, headache, fever, sore throat, and dyspnea are common symptoms caused by all three viruses, i.e., SARS-CoV, MERS-CoV, and SARS-CoV-2. Though, COVID-19 patients exhibit lesser gastrointestinal involvement as compared to patients suffering from MERS and SARS [118]. Patients infected with MERS have a higher occurrence of renal failure, which, even though is characteristic, is not commonly found in other types of coronavirus infections in humans $[119,120]$.

\section{Effect of ACE-2 on SARS-CoV-2 Infection}

A transmembrane trimetric glycoprotein that protrudes from the viral surface makes up the spike and determines the host tropism and the diversity of the coronaviruses. There are two functional sub-units of a spike where subunit S1 performs the function of binding to host cell receptors, and subunit $\mathrm{S} 2$ works for the fusion of cellular and viral membranes. The functional receptor for SARS-CoV has been identified as the ACE2 [121]. It has been shown through structural and functional analysis that ACE2 binds to spike for SARS-CoV-2 [122-124]. The expression for ACE2 was on the higher side in the heart, kidney lung, ileum, and bladder [125]. Inside the lung, lung epithelial cells had a higher expression of ACE2. This is associated with heart function and the development of systemic diseases such as diabetes mellitus, and hypertension. Besides the above, it has been earmarked as the main receptor for coronaviruses, such as SARS-CoV and SARS-CoV-2. SARS-CoV-2 (causing COVID-19 infection) is activated by binding the $S$ glycoprotein to ACE2, which is expressed in the lungs and heart [126]. The virus SARS-CoV-2 has been reported to primarily attack alveolar epithelial cells, which results in severe respiratory symptoms (Figure 4). These symptoms have been reported to have a severe exhibition in cardiovascular disease patients, and this might be linked with increased secretion of ACE2 among these patients compared with healthy individuals. It can be noted that ACE2 levels can be upregulated by using renin-angiotensin-aldosterone system inhibitors [127]. Since ACE2 has been found as the functional receptor for SARS-CoV-2 infection, it is important to be vigilant for the potential effects of antihypertensive treatment using ACE inhibitors or angiotensinreceptor blockers (ARBs) in patients with COVID-19. The switching of the antihypertensive agent from ACE inhibitors/ARBs in COVID-19-infected individuals with hypertension as an underlying disease to other treating agents is seemingly controversial and requires adducing solidly for the same [128]. 


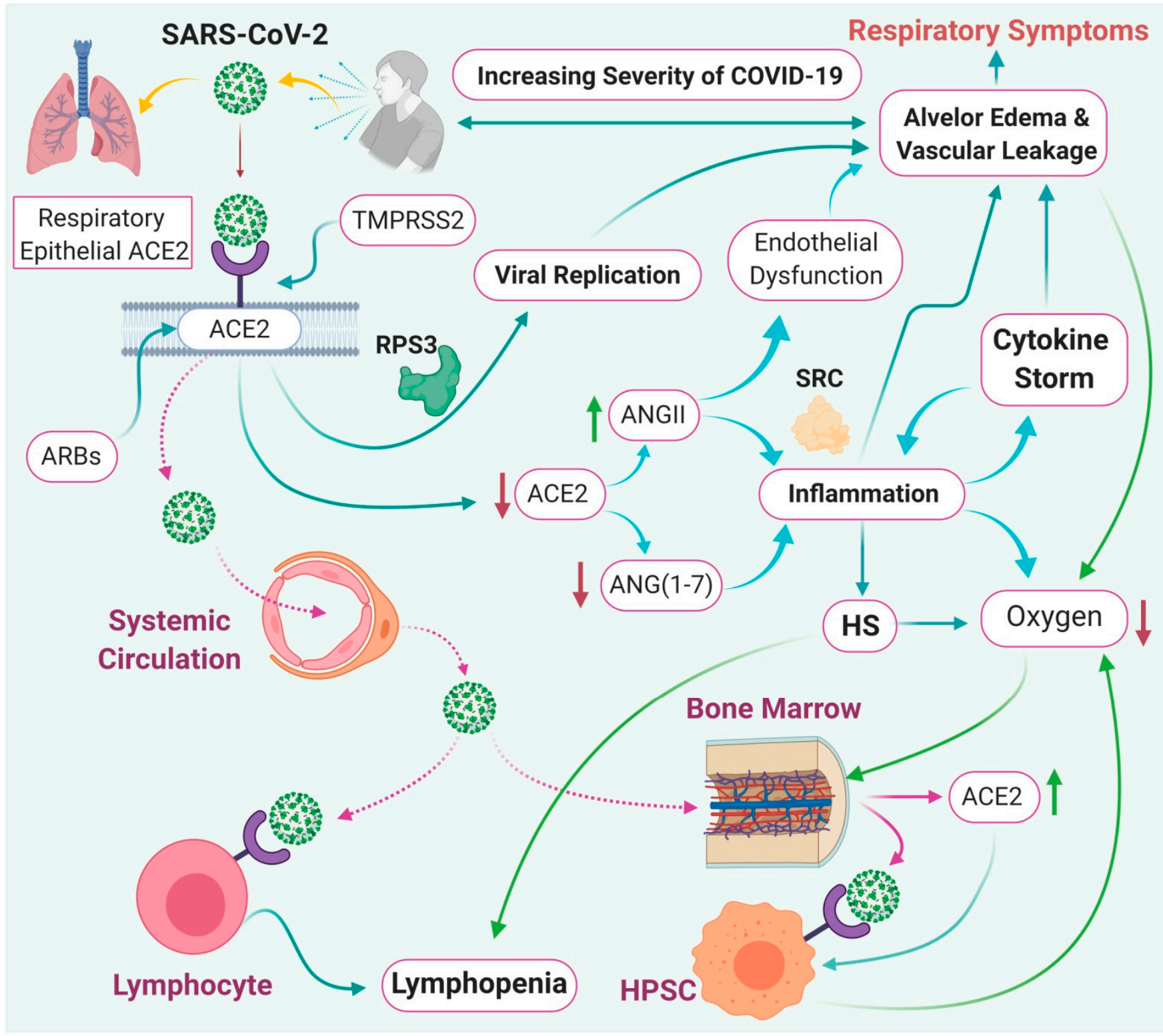

Figure 4. This schematic describes the proposed mechanistic role of ACE2 on SARS-CoV-2 infection. The SARS-CoV-2 virus uses the ACE2 receptor to gain entry into the cell (airway epithelial cells), leading to an increase in proinflammatory cytokines and the development of cytokine storm, which lead to lung damage and augmented COVID-19 severity. Angiotensin receptor blockers (ARBs) might increase the expression of ACE2, and TMPRSS2 assists in S protein priming, leading to enhanced binding of SARS-CoV-2 and higher proinflammatory cytokine release. The higher expression of ACE2 is reported to affect SRC and RPS3, the two crucial genes engaged in inflammatory responses and viral replication. Further, the expression of ACE2, at the same time, is enhanced by the infection. It is also evident that at the same time, SARS-CoV-2 may downregulate ACE2 expression, which further contributes to an increase in angiotensin-2-induced lung injury. The ACE2-mediated negative regulatory activity is curtailed by SARS-CoV-2 and contributes to aggravating the severity of illness.

Recently, it has been found that there was no significant difference in the expression level of the ACE2 in individuals with pre-existing comorbidities when compared to healthy populations. However, long-term smoking has been speculated as a risk factor for SARS-CoV-2 infection following the reporting of the elevated expression of ACE2 among cigarette smokers. The analytical findings of ACE2 in SARS-CoV-2-infected cells suggested the involvement of ACE2 receptors to have a regulatory role in the immune response, cytokine secretion, and replication of virus at post-infectious state, also acting as a binding 
receptor to facilitate viral entry. Indeed, these findings may render potential insight into the pathogenesis of COVID-19 in the purview of designing effective therapeutic strategies for battling SARS-CoV-2 infection.

It requires further investigation to determine whether SARS-CoV-2 binds to an additional target. The spike protein undergoes protease cleavage after the host protein binds to SARS-CoV-2. A model was proposed to activate spike protein of SARS-CoV and MERSCoV comprising a two-step sequential protease cleavage, which, for priming, comprises cleavage at the S1/S2 cleavage site and, for activation, cleavage at the S1 site, which is within the S2 subunit and is a position that is adjacent to a fusion peptide [129-131]. S1 and S2 subunits remain non-covalently bound. The distal S1 subunit contributes to the prefusion state after cleavage at the S1/S2 cleavage site and stabilization of the membraneanchored S2 subunit [123]. Presumably, the spike for the membrane fusion is activated by the subsequent cleavage at the $S^{\prime} 2$ site through conformational and irreversible changes. This spike of the coronavirus is unusual amongst the viruses because it can be cleaved and activated through a wide range of varied proteases [132]. The existence of the furin cleavage site at the S1/S2 site, is a characteristic that is unique to SARS-CoV-2. During the biosynthesis, the S1/S2 site of the SARS-CoV-2 is completely subjected to cleavage, which is in drastic contrast to the SARS-CoV spike that has been included in the assembly without cleavage [123]. The cleavage was subjected upon the S1/D2 site through varied proteases such as cathepsin L and TMPRSS2, and the virus is made extremely pathogenic by the ubiquitous expression of furin [131,133].

\section{Immunopathological Mechanisms of SARS-CoV-2 Infection}

When considered at the whole-genome level, close relations have been found between SARS-CoV-2 and bat-SL-CoVZC45 and bat-SL-CoVZXC21, albeit its receptor binding is identical to that of SARS-CoV [134]. Though, it is pertinent to mention here that species specificity is not solely determined by receptor recognition. After binding to the receptive receptor, the innate immune response is generated to counteract the entry of the SARSCoV-2 into host cells. The innate immune signaling evasion or inhibition is necessary for infecting its new host and enhancing viral productivity. Though, how SARS-CoV-2 has driven the pathogenesis as well as evade the immune response is still unknown. SARSCoV-2 seemingly shares an identical pathological mechanistic to that of SARS-CoV, as SARS and COVID-19 exhibit similar clinical features [38]. While responding to the SARS-CoV-2 infections, for inhibiting the replication of the virus, expression of IFN-stimulated genes (ISGs) is stimulated by the type I interferon (IFN) system.

SARS-CoV-2 encodes over eight viral antagonists that evade the ISG effector function and modulate the induction of cytokines and IFN to overcome the antiviral activity [135]. To inhibit the dissemination and replication of the virus, the host immune system responds via cellular antiviral activity and plays a critical role in subjugating inflammation. However, there is a likelihood of pathological implications coming into play due to the lytic effects of the virus on host cells and exacerbated immune response. The studies that include fever, dry cough, breathlessness, hypoxia, and severe pneumonia have identified the symptomatology in COVID-19 diseased patients $[38,113]$. Some patients witnessed rapid progression combined with Acute Respiratory Distress Syndrome (ARDS), Systemic Inflammatory Response Syndrome (SIRS), and Multi-Organ Dysfunction Syndrome (MODS) that lead to death in approximately $10 \%$ of the patients due to the presence of ACE2 receptor in cardiac, renal, and hepatic tissues [113,136](Figure 3). The evolution of diffuse alveolar damage is due to the increased levels of IFN- $\gamma$-induced protein 10 (IP10), pro-inflammatory cytokines (IL-1, -2, -6, -8, -10, and -12), interferon-gamma (IFN- $\gamma$ ), monocyte chemoattractant protein-1 (MCP1), and macrophage inflammatory proteins-1A (MIP1A), in patients diagnosed with SARS [137] (Figure 3). A similar picture of immunopathology has been observed in patients infected with SARS-CoV-2. Significantly higher levels of IP10, MCP1, GSCF, and TNF- $\alpha$ have witnessed in patients admitted to the ICU (intensive care unit) as 
compared to non-ICU patients, suggesting that the underlying cause of the severity of the disease can be cytokine storm [38].

Against all expectations, an uncommon phenomenon was seen during the acute phase of the viral infection wherein IL-10 and IL-4 anti-inflammatory cytokines were also increased in those patients [38]. One more interesting finding that has been explained before was that older males are more likely to be infected with SARS-CoV-2 as compared to children, with rare cases being reported in that age group [38,113]. With SARS-CoV-2, the same observation was found in primate models where the aged cynomolgus macaque was found to be more likely to be infected by the virus as compared to young adults [138]. The identification of the host genes of SARS-CoV-2 and virulence factors that facilitate virus crossing of species-specific barrier mandates further studies to recognize the cause of the lethal disease in humans.

\section{Diagnosis of COVID-19}

There are several ways to diagnose and test the impact of SARS-CoV-2 infection such as complete hematological profiling with cellular counts; functional assays of the liver and kidney with the estimate of their enzyme markers and urea levels, respectively; detection of the pathogenic DNA from quantitative PCR or the nucleic acid amplification test; inflammatory markers such as CK-MB, ESR, CRP, D-dimer, ferritin, IL-6, and procalcitonin; and radiological investigations such as chest radiographs, ultrasound, and CT. Quantitative real-time PCR is the mainstay in diagnosing COVID-19 due to its sensitivity, specificity, and feasibility as compared to viral culture. It is the gold standard diagnostic approach with high sensitivity to the viral detection. Elevated procalcitonin levels may also show a superinfection of SARS-CoV-2, as the viral infection may cause a superinfection with bacteria. Similarly, increased levels of biological markers such as IL-6, CRP, ferritin, LDH, Ddimer, and ESR may signify the critical stage of SARS-CoV-2 infection. Further, estimating the complete blood picture report including the count of $\mathrm{RBC}, \mathrm{WBC}$, and platelets is another approach to examine SARS-CoV-2 infection. Common laboratory abnormalities present amongst the patients suffering from COVID-19 include prolonged prothrombin time, lymphopenia, and elevated lactate dehydrogenase $[37,111,113]$. Compared to nonICU patients, patients admitted to ICU exhibited higher laboratory abnormalities $[38,111]$. Some patients exhibited elevation in levels of creatine kinase, aminotransferase, creatinine, and C-reactive protein $[26,37,38]$. Normal serum procalcitonin levels were seen in most of the patients $[37,38,111]$. High levels of IFN- $\gamma$, IP10, IL1 $\beta$, and MCP1 are present in COVID-19 patients. Importantly, ICU-admitted patients tend to have higher levels of MCP1A, MIP1A, granulocyte-colony stimulating factor (GCSF), IP10, and TNF- $\alpha$ [38]. Further, there can be variations of radiology findings in patients according to immunity status, disease progression, comorbidity, age, and initial medical intervention [139]. In a study conducted amongst the initial 41 cases of 2019-nCoV infection, all 41 patients were suffering from pneumonia, and chest computer tomography (CTscan) showed abnormal findings [38]. In another study comprising six patients, patients who showed multifocal patchy opacities with ground-glass appearances in the peripheral sections of the lungs also exhibited abnormalities on the chest CTscan [26]. As per the data derived from studies, consolidative pulmonary opacities and bilateral pulmonary parenchymal ground-glass are the typical findings of chest CTscans $[37,38,111-113,140]$. Lung consolidation was noted predominantly among patients five or more days from the onset of disease and those who were 50 years or older compared to those at four or fewer days from onset and those who were 50 years or younger [141]. Manifested by extension and increasing density of the lung opacities, the progression of the disease was noted to be mild to moderate as the course of the disease continued [142]. Sub-segmental and bilateral multiple lobular areas of consolidation are the common findings on chest CTscan in ICU-admitted patients [38]. In a study conducted amongst 99 patients, imaging examination revealed pneumothorax in one patient [113]. The overall diagnosis methods are presented in Figure 5. 


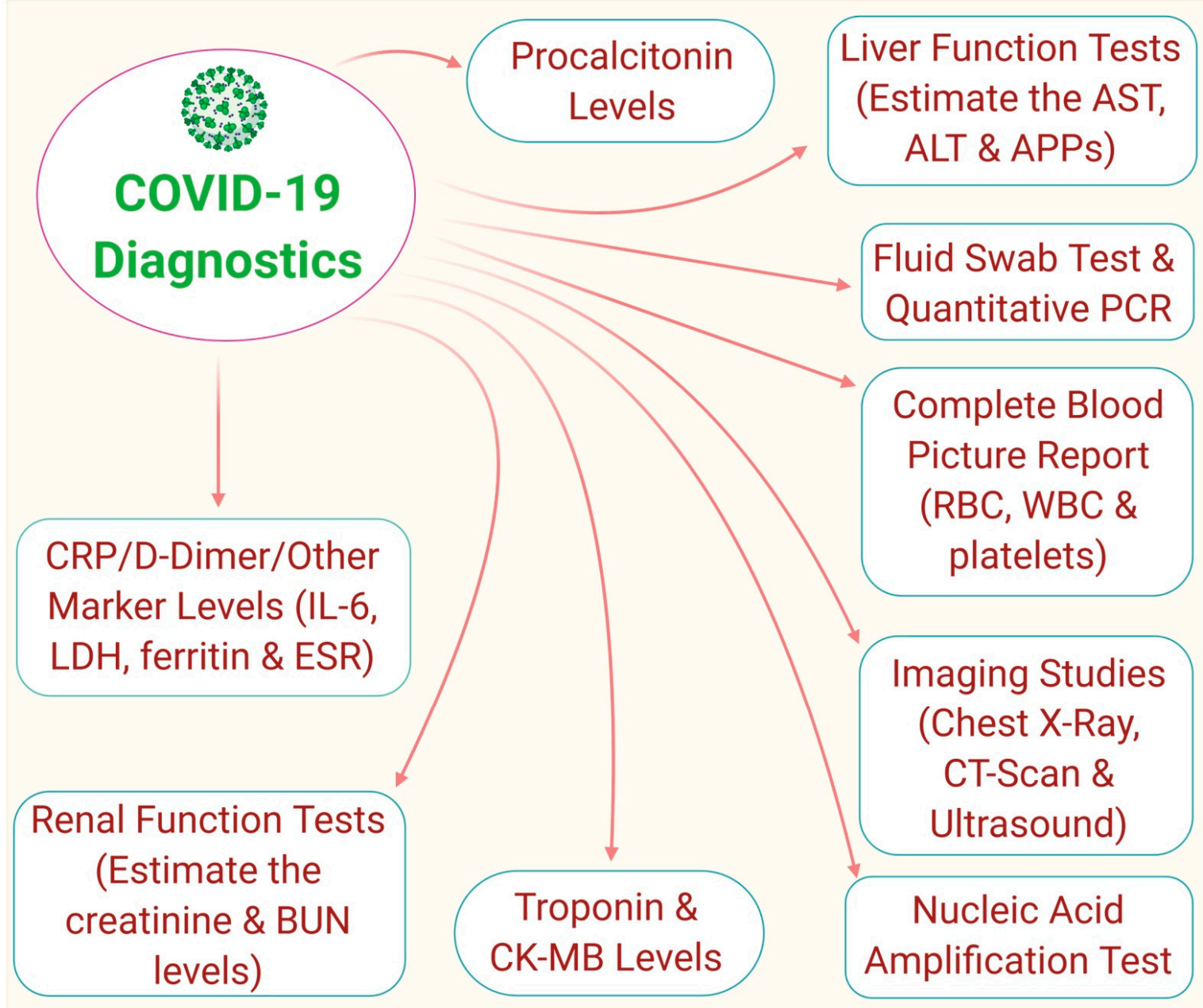

Figure 5. Schematic depiction showing various diagnosis and testing ways of COVID-19.

\section{Therapeutic Strategies}

Unfortunately, to date, no single medication has been reported or proposed to combat the infective viral load of SARS-CoV-2. However, previous strategies for developing proper medications to pulverize SARS-CoV can be extrapolated to COVID-19 infection effectively. Scientists, several research groups, and clinicians across the globe are working towards finding effective medications that can curtail or eliminate the viral load of SARS-CoV-2. Yet, a definitive treatment to fight COVID-19 needs to be announced across the nations. Further, identifying and implementing various natural products, antiviral drugs, anti-malarial drugs, and vaccines can aid in the treatment of the ongoing pandemic (Figure 6). Social distancing, hand washing, self-isolation, fluid management, oxygen therapy (supportive care), and antibiotics treatment for secondary bacterial infections have been recommended [143]. The deployment of primary prevention of risk factors (social distancing, hand washing, face masks, and other infection control measures) hasbeen addressed and propagated to contain the novel coronaviral agent among communities [144]. Since proper evidencebased treatment was not available for COVID-19, the WHO has framed the guidelines to manage the disease based on triage. Once sepsis in COVID-19 patients is suspected, the rational use of multiple antibiotics and glucocorticoids to control the cytokine storm was suggested. The routine use of glucocorticoid administration is not recommended until and unless it is definitively indicated [144]. Corticosteroid treatment is also not prescribed, as evidenced by several clinical studies [145]. A few studies suggested that the administration 
of intravenous immunoglobulin might help in combating SARS-CoV-2 infection in severely ill patients [146].

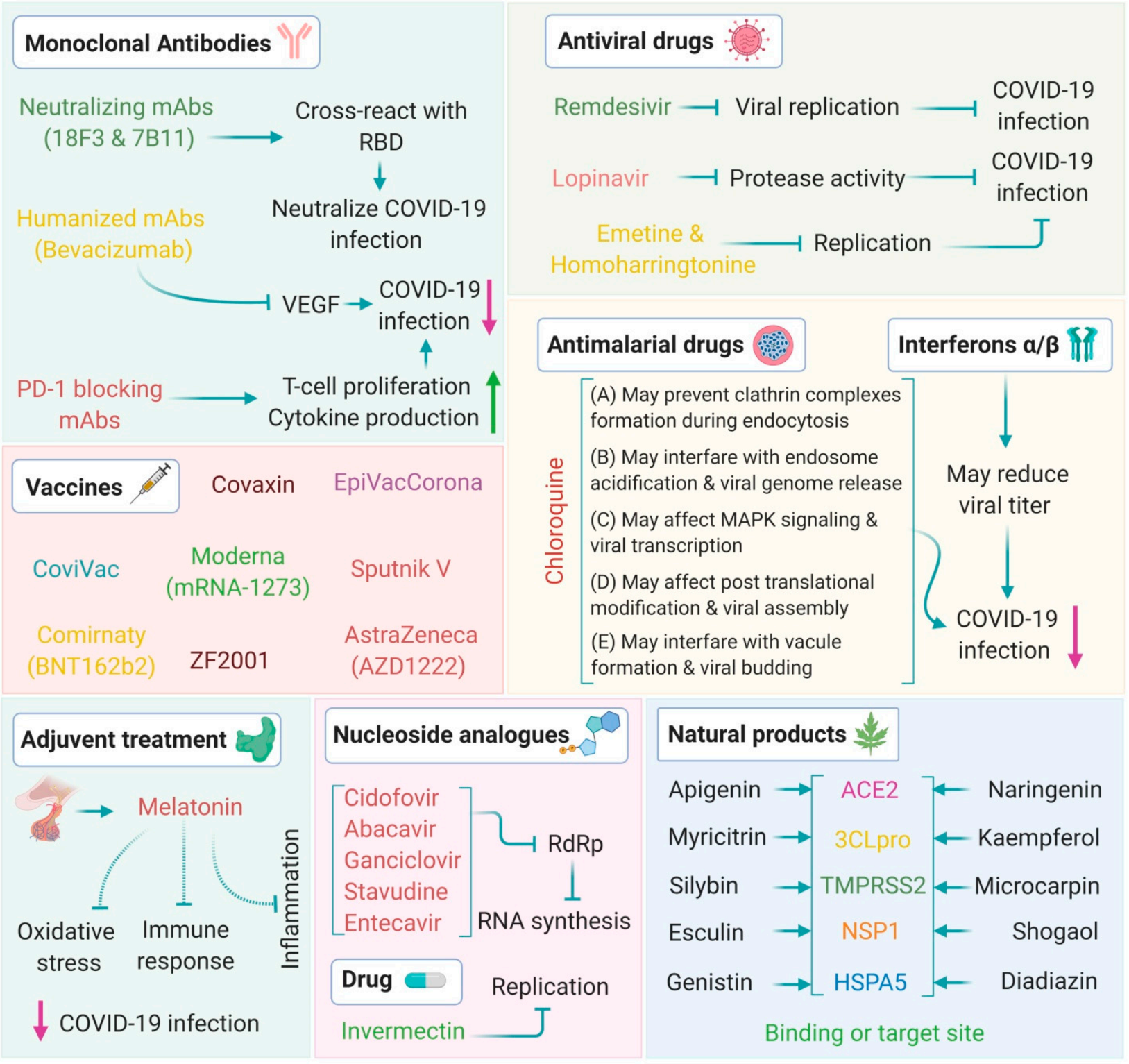

Figure 6. Possible therapeutic strategies to combat SARS-CoV-2 infection.

\subsection{Antiviral Drugs}

There are no proven studies available to state that anti-viral treatment can combat SARS-CoV-2 infections. Initially, anti-viral drugs, broad-spectrum antibiotics, and effective nebulization of IFN- $\alpha$ had been utilized to curtail this load; though, only a few drugs have displayed their potential impact against the virus [147-149]. Aligning to prior therapeutics investigations for treating MERS and SARS infection, drugs are being evaluated [150]. In general, there is a lack of strong evidence that antiviral drugs can considerably improve the clinical outcomes. Researchers have also used the anti-influenza drug oseltamivir in combination with empirical antibiotics as a cocktail in the management of COVID-19 patients [38]. Similarly, in the US, Remdesivir developed for the Ebola virus has been recently utilized along with other antimicrobials to combat COVID-19 [151]. Certain potential clinical advantages were observed on a few COVID-19 patients when administered with the combination of Arbidol/ShufengJiedu Capsule (SFJDC) and Ritonavir/Lopinavir [111]. To 
examine the safety and effectiveness of Lopinavir/Ritonavir and interferon-2b in COVID-19 patients, a clinical study is under trial [143]. A broad-spectrum antiviral drug, Remdesivir, a nucleotide analog RNA polymerase inhibitor, has shown efficacy against SARS-CoV-2 in in-vitro and in-vivo studies and clinical trials [12,122]. It has been reported that patients suffering from coronaviruses were affirmed as clinically recovered after the administration of Remdesivir. This antiviral drug alone or in combination with chloroquine or IFN- $\beta$ significantly blocks SARS-CoV-2 replication [151,152]. Intravenous Remdesivir cured the first case of COVID-19 reported from the USA, along with other supportive care [12]. However, the establishment of definitive effects of Remdesivir on SARS-CoV-2 further warrants detailed research work in animals and clinical sample-based settings. A range of other antiviral drugs is presently under evaluation against SARS-CoV-2 infection. In vitro studies on Nitazoxanide, Nafamostat, Penciclovir, Ribavirin, Arbidol, Favipiravir, Ritonavir, Baricitinib, and AAK1 showed moderate results against COVID-19 [111,151-153]. Similarly, several other combinations, including combining traditional Chinese medicines with antiviral or antibiotics, have been evaluated in humans and mice against SARS-CoV2-induced infection [152]. Additionally, the drugs from existing antiviral categories hold scope for future prospects $[154,155]$ (Table 3).

Table 3. List of natural products/isolated compounds or their derivatives and drugs that inhibit the coronavirus family.

\begin{tabular}{|c|c|c|c|c|}
\hline Categories & Compound Name & Proposed Mode of Actions & Involved Viruses & References \\
\hline \multirow{6}{*}{ Antiviral drugs } & $\begin{array}{c}\text { Remdesivir (GS-5734, } \\
\text { Nucleoside analogue of } \\
\text { Remdesivir triphosphate) } \\
\text { (RDV-TP) }\end{array}$ & Inhibitor of RdRp & SARS-CoV-2 & [156] \\
\hline & Lopinavir/Ritonavir & HIV protease inhibitor & $\begin{array}{l}\text { HIV infection, } \\
\text { SARS-CoV-1, and } \\
\text { MERS-CoV }\end{array}$ & {$[157,158]$} \\
\hline & Darunavir/Cobicistat & Protease inhibitor & SARS-CoV-2 & [159] \\
\hline & $\begin{array}{c}\text { Favipiravir (T-705) Purine } \\
\text { nucleotide }\end{array}$ & RNA polymerase inhibitor & $\begin{array}{l}\text { RNA viruses and } \\
\text { SARS-CoV-2 }\end{array}$ & [160] \\
\hline & $\begin{array}{l}\text { Ribavirin (Guanine } \\
\text { analogue) }\end{array}$ & Inhibits viral RdRp & $\begin{array}{l}\text { SARS-CoV-1 and } \\
\text { SARS-CoV-2 }\end{array}$ & [161] \\
\hline & Umifenovir (Arbidol) & $\begin{array}{l}\text { Targeting the S } \\
\text { protein/ACE2 and inhibits } \\
\text { the membrane fusion of the } \\
\text { envelope of the virus }\end{array}$ & $\begin{array}{l}\text { Influenza and } \\
\text { SARS-CoV-2 }\end{array}$ & {$[162,163]$} \\
\hline \multirow[t]{2}{*}{ Antimalarial drugs } & $\begin{array}{l}\text { Chloroquine (Synthetic } \\
\text { version of quinine and is } \\
\text { found in the bark of } \\
\text { cinchona trees) }\end{array}$ & $\begin{array}{l}\text { Reduces the rate of } \\
\text { replication }\end{array}$ & $\begin{array}{l}\text { Malaria, systemic } \\
\text { inflammatory diseases, } \\
\text { and SARS-CoV-2 }\end{array}$ & [164] \\
\hline & Hydroxychloroquine & $\begin{array}{c}\text { Inhibition of glycosylation of } \\
\text { host receptors, proteolytic } \\
\text { processing, and acidification } \\
\text { of endosomes }\end{array}$ & $\begin{array}{l}\text { SARS-CoV-2 and } \\
\text { autoimmune diseases }\end{array}$ & [165] \\
\hline \multirow[t]{2}{*}{ Antiparasitic drugs } & Ivermectin & Inhibits nuclear transport & $\begin{array}{l}\text { Parasitic Infections and } \\
\text { SARS-CoV-2 }\end{array}$ & [166] \\
\hline & $\begin{array}{c}\text { Nitazoxanide } \\
\text { (Anti-helminthic drug) }\end{array}$ & Unclear & MERS and SARS-CoV-2 & [167] \\
\hline
\end{tabular}


Table 3. Cont.

\begin{tabular}{|c|c|c|c|c|}
\hline Categories & Compound Name & Proposed Mode of Actions & Involved Viruses & References \\
\hline \multirow{5}{*}{ Adjunctive drugs } & $\begin{array}{l}\text { Corticosteroids/quinolone } \\
\text { (n combination) }\end{array}$ & Prevents ARDS & $\begin{array}{l}\text { SARS-CoV and } \\
\text { SARS-CoV-2 }\end{array}$ & [168] \\
\hline & $\begin{array}{l}\text { Monoclonal Antibodies } \\
\text { (Tocilizumab, Sarilumab, } \\
\text { Eculizumab, Fingolimod, } \\
\text { Bevacizumab) }\end{array}$ & $\begin{array}{c}\text { Immunomodulatory effect, } \\
\text { inhibition of terminal } \\
\text { complement, and anti-VEGF } \\
\text { medication }\end{array}$ & $\begin{array}{l}\text { SARS-CoV-2 and } \\
\text { Chronic Inflammatory } \\
\text { disorders }\end{array}$ & {$[169,170]$} \\
\hline & $\begin{array}{l}\text { ACE-Inhibitors and ARBs } \\
\text { (enzyme) }\end{array}$ & Activates RAAS mechanism & SARS-CoV-2 & [171] \\
\hline & Interferon- $(\alpha$ and $\beta)$ & Unclear & $\begin{array}{l}\text { MERS-CoV and } \\
\text { SARS-CoV-2 }\end{array}$ & [161] \\
\hline & $\begin{array}{l}\text { Vitamin-D (Adjunct with } \\
\text { vitamin C and zinc) }\end{array}$ & $\begin{array}{l}\text { Inhibits inflammatory } \\
\text { response and attenuates } \\
\text { cytokine storm }\end{array}$ & SARS-CoV-2 & {$[172,173]$} \\
\hline
\end{tabular}

\subsection{Vaccines}

Usually, vaccine preparation is a three-phase (I, II, III) trial-based procedure. The conduction of phase I trial aims at checking the generation of immune response by enrolling only multiples of 10 (approximately $30-40$ ) individuals. A successful phase I trial proceeds further to phase II with the further enrollment of hundreds of individuals, wherein the aim is to identify the dosage concentrations, immunogenicity, and safety. Finally, the phase III trial will include the enrollment of thousands of individuals for measuring the efficacy of the vaccine in terms of its immune response against the targeted disease infection. Currently, multiple companies/universities are investigating the development of a vaccination against SARS-CoV-2 with the Coalition for Epidemic Preparedness Innovations [174]. Here we have collated the information on various vaccines that are approved (Table 4) and underdevelopment (Table 5) along with their respective details.

Table 4. List of approved vaccines for COVID-19; data retrieved from https: / www.raps.org/news-and-articles / newsarticles /2020/3/covid-19-vaccine-tracker, accessed on 14 March 2021.

\begin{tabular}{|c|c|c|c|c|c|}
\hline S.No & Name & Vaccine Type & Primary Developer & Country of Origin & $\begin{array}{l}\text { List of Countries Approved } \\
\text { for Use }\end{array}$ \\
\hline 1 & $\begin{array}{l}\text { Comirnaty } \\
\text { (BNT162b2) }\end{array}$ & $\begin{array}{l}\text { mRNA-based } \\
\text { vaccine }\end{array}$ & $\begin{array}{c}\text { Pfizer, BioNTech; Fosun } \\
\text { Pharma }\end{array}$ & Multinational & $\begin{array}{l}\text { Albania, Andorra, Argentina, } \\
\text { Aruba, Australia, Bahrain, } \\
\text { Brazil, Canada, Caribbean, } \\
\text { Chile, Colombia, Costa Rica, } \\
\text { Ecuador, EU, Faroe Islands, } \\
\text { Greenland, Hong Kong, Iceland, } \\
\text { Iraq, Israel, Japan, Jordan, } \\
\text { Kuwait, Liechtenstein, Malaysia, } \\
\text { Mexico, Monaco, New Zealand, } \\
\text { North Macedonia, Norway, } \\
\text { Oman, Panama, Philippines, } \\
\text { Qatar, Rwanda, Saint Vincent } \\
\text { and the Grenadines, Saudi } \\
\text { Arabia, Serbia, Singapore, South } \\
\text { Korea, Suriname, Switzerland, } \\
\text { UAE, UK, US, Vatican City, } \\
\text { WHO }\end{array}$ \\
\hline
\end{tabular}


Table 4. Cont.

\begin{tabular}{|c|c|c|c|c|c|}
\hline S.No & Name & Vaccine Type & Primary Developer & Country of Origin & $\begin{array}{l}\text { List of Countries Approved } \\
\text { for Use }\end{array}$ \\
\hline 2 & $\begin{array}{l}\text { Moderna } \\
\text { COVID-19 } \\
\text { Vaccine } \\
\text { (mRNA- } \\
\text { 1273) }\end{array}$ & $\begin{array}{l}\text { mRNA-based } \\
\text { vaccine }\end{array}$ & $\begin{array}{l}\text { Moderna, BARDA, } \\
\text { NIAID }\end{array}$ & US & $\begin{array}{l}\text { Canada, EU, Faroe Islands, } \\
\text { Greenland, Iceland, Israel, } \\
\text { Liechtenstein, Norway, Qatar, } \\
\text { Saint Vincent and the } \\
\text { Grenadines, Singapore, } \\
\text { Switzerland, United Kingdom, } \\
\text { United States, Vietnam }\end{array}$ \\
\hline 3 & $\begin{array}{l}\text { COVID-19 } \\
\text { Vaccine As- } \\
\text { traZeneca } \\
\text { (AZD1222); } \\
\text { also known } \\
\text { as } \\
\text { Covishield }\end{array}$ & $\begin{array}{l}\text { Adenovirus } \\
\text { vaccine }\end{array}$ & BARDA, OWS & UK & $\begin{array}{l}\text { Australia, Argentina, Bahrain, } \\
\text { Bangladesh, Barbados, Brazil, } \\
\text { Canada, Chile, Dominican } \\
\text { Republic, Ecuador, El Salvador, } \\
\text { Egypt, EU, Ghana, Guyana, } \\
\text { Hungary, India, Indonesia, Iraq, } \\
\text { Ivory Coast, Malaysia, } \\
\text { Maldives, Mauritius, Mexico, } \\
\text { Morocco, Myanmar, Nepal, } \\
\text { Nigeria, Pakistan, Philippines, } \\
\text { Saint Vincent and the } \\
\text { Grenadines, South Africa, South } \\
\text { Korea, Sri Lanka, Taiwan, } \\
\text { Thailand, UK, Vietnam }\end{array}$ \\
\hline 4 & Sputnik V & $\begin{array}{l}\text { Recombinant } \\
\text { adenovirus vaccine } \\
\text { (rAd26 and rAd5) }\end{array}$ & $\begin{array}{l}\text { Gamaleya Research } \\
\text { Institute, Acellena } \\
\text { Contract Drug Research } \\
\text { and Development }\end{array}$ & Russia & $\begin{array}{l}\text { Algeria, Angola, Argentina, } \\
\text { Armenia, Bahrain, Belarus, } \\
\text { Bolivia, Congo, Djibouti, Egypt, } \\
\text { Gabon, Ghana, Guatemala, } \\
\text { Guinea, Guyana, Honduras, } \\
\text { Hungary, Iran, Iraq, Jordan, } \\
\text { Kazakhstan, Kenya, Kyrgyzstan, } \\
\text { Laos, Lebanon, Mexico, } \\
\text { Moldova, Mongolia, } \\
\text { Montenegro, Morocco, } \\
\text { Myanmar, Nicaragua, North } \\
\text { Macedonia, Pakistan, Palestine, } \\
\text { Paraguay, Republika Srpska, } \\
\text { Russia, Saint Vincent and the } \\
\text { Grenadines, San Marino, Serbia, } \\
\text { Slovakia, Sri Lanka, Syria, } \\
\text { Tunisia, Turkmenistan, United } \\
\text { Arab Emirates, Uzbekistan, } \\
\text { Venezuela, Zimbabwe }\end{array}$ \\
\hline 5 & $\begin{array}{l}\text { COVID-19 } \\
\text { Vaccine } \\
\text { Janssen } \\
\text { (JNJ- } \\
\text { 78436735; } \\
\text { Ad26.COV2.S) }\end{array}$ & $\begin{array}{l}\text { Non-replicating } \\
\text { viral vector }\end{array}$ & $\begin{array}{l}\text { Janssen Vaccines } \\
\text { (Johnson \& Johnson) }\end{array}$ & $\begin{array}{l}\text { The Netherlands, } \\
\text { US }\end{array}$ & $\begin{array}{c}\text { Bahrain, Canada, EU, Saint } \\
\text { Vincent and the Grenadines, US, } \\
\text { WHO }\end{array}$ \\
\hline 6 & CoronaVac & $\begin{array}{l}\text { Inactivated vaccine } \\
\text { (formalin with } \\
\text { alum adjuvant) }\end{array}$ & Sinovac & China & $\begin{array}{c}\text { Azerbaijan, Bolivia, Brazil, } \\
\text { Cambodia, China, Chile, } \\
\text { Colombia, Ecuador, Hong Kong, } \\
\text { Indonesia, Laos, Malaysia, } \\
\text { Mexico, Thailand, Tunisia, } \\
\text { Turkey, Philippines, Ukraine, } \\
\text { Uruguay, Zimbabwe }\end{array}$ \\
\hline
\end{tabular}


Table 4. Cont.

\begin{tabular}{|c|c|c|c|c|c|}
\hline S.No & Name & Vaccine Type & Primary Developer & Country of Origin & $\begin{array}{l}\text { List of Countries Approved } \\
\text { for Use }\end{array}$ \\
\hline 7 & $\begin{array}{l}\text { BBIBP- } \\
\text { CorV }\end{array}$ & Inactivated vaccine & $\begin{array}{l}\text { Beijing Institute of } \\
\text { Biological Products; } \\
\text { China National } \\
\text { Pharmaceutical Group } \\
\text { (Sinopharm) }\end{array}$ & China & $\begin{array}{c}\text { Argentina, Bahrain, Cambodia, } \\
\text { China, Egypt, Hungary, Iraq, } \\
\text { Jordan, Laos, Macau, Morocco, } \\
\text { Nepal, Pakistan, Peru, Senegal, } \\
\text { Serbia, Seychelles, UAE, } \\
\text { Venezuela, Zimbabwe }\end{array}$ \\
\hline 8 & EpiVacCorona & Peptide vaccine & $\begin{array}{c}\text { Federal Budgetary } \\
\text { Research Institution } \\
\text { State Research Center of } \\
\text { Virology and } \\
\text { Biotechnology }\end{array}$ & Russia & Russia, Turkmenistan \\
\hline 9 & $\begin{array}{l}\text { Convidicea } \\
\text { (Ad5- } \\
\text { nCoV) }\end{array}$ & $\begin{array}{c}\text { Recombinant } \\
\text { vaccine } \\
\text { (adenovirus type } 5 \\
\text { vector) }\end{array}$ & CanSino Biologics & China & Mexico, China, Pakistan \\
\hline 10 & Covaxin & Inactivated vaccine & Bharat Biotech, ICMR & India & India, Zimbabwe \\
\hline 11 & $\begin{array}{l}\text { No name } \\
\text { announced }\end{array}$ & Inactivated vaccine & $\begin{array}{l}\text { Wuhan Institute of } \\
\text { Biological Products; } \\
\text { China National } \\
\text { Pharmaceutical Group } \\
\text { (Sinopharm) }\end{array}$ & China & China \\
\hline 12 & CoviVac & Inactivated vaccine & $\begin{array}{l}\text { Chumakov Federal } \\
\text { Scientific Center for } \\
\text { Research and } \\
\text { Development of } \\
\text { Immune and Biological } \\
\text { Products }\end{array}$ & Russia & Russia \\
\hline 13 & ZF2001 & $\begin{array}{l}\text { Recombinant } \\
\text { vaccine }\end{array}$ & $\begin{array}{c}\text { Anhui ZhifeiLongcom } \\
\text { Biopharmaceutical, } \\
\text { Institute of Microbiology } \\
\text { of the Chinese Academy } \\
\text { of Sciences }\end{array}$ & China, Uzbekistan & Uzbekistan \\
\hline
\end{tabular}

Table 5. List of vaccine candidates under development along with their clinical trial stages; data retrieved from https: //www.raps.org/news-and-articles/news-articles/2020/3/covid-19-vaccine-tracker, accessed on 14 March 2021.

\begin{tabular}{cccccc}
\hline S.No & Candidate Name & Vaccine Type & Sponsor/Developer & $\begin{array}{c}\text { Clinical Trial } \\
\text { Stage }\end{array}$ & Companies/Universities \\
\hline 1 & NVX-CoV2373 & $\begin{array}{c}\text { Nanoparticle } \\
\text { vaccine }\end{array}$ & Novavax & Phase 3 & Novavax \\
\hline 2 & ZyCoV-D & $\begin{array}{c}\text { DNA vaccine } \\
\text { (plasmid) }\end{array}$ & Zydus Cadila & Phase 3 & Zydus Cadila \\
\hline 3 & Abdala (CIGB 66) & $\begin{array}{c}\text { Protein subunit } \\
\text { vaccine }\end{array}$ & $\begin{array}{c}\text { Center for Genetic } \\
\text { Engineering and } \\
\text { Biotechnology }\end{array}$ & Phase 3 & $\begin{array}{c}\text { Center for Genetic } \\
\text { Engineering and } \\
\text { Biotechnology }\end{array}$ \\
\hline 4 & CVnCoV & $\begin{array}{c}\text { mRNA-based } \\
\text { vaccine }\end{array}$ & CureVac; GSK & Phase 2b/3 & CureVac
\end{tabular}


Table 5. Cont.

\begin{tabular}{|c|c|c|c|c|c|}
\hline S.No & Candidate Name & Vaccine Type & Sponsor/Developer & $\begin{array}{l}\text { Clinical Trial } \\
\text { Stage }\end{array}$ & Companies/Universities \\
\hline 5 & $\begin{array}{l}\text { Bacillus } \\
\text { Calmette-Guerin } \\
\text { (BCG) vaccine }\end{array}$ & $\begin{array}{l}\text { Live-attenuated } \\
\text { vaccine }\end{array}$ & $\begin{array}{c}\text { University of } \\
\text { Melbourne and } \\
\text { Murdoch } \\
\text { Children's } \\
\text { Research Institute; } \\
\text { Radboud } \\
\text { University Medical } \\
\text { Center; Faustman } \\
\text { Lab at } \\
\text { Massachusetts } \\
\text { General Hospital }\end{array}$ & Phase $2 / 3$ & $\begin{array}{l}\text { University of Melbourne and } \\
\text { Murdoch Children's Research } \\
\text { Institute; Radboud University } \\
\text { Medical Center; Faustman } \\
\text { Lab at Massachusetts General } \\
\text { Hospital }\end{array}$ \\
\hline 6 & INO-4800 & $\begin{array}{l}\text { DNA vaccine } \\
\text { (plasmid) }\end{array}$ & $\begin{array}{c}\text { Inovio } \\
\text { Pharmaceuticals }\end{array}$ & Phase $2 / 3$ & $\begin{array}{l}\text { Center for Pharmaceutical } \\
\text { Research, Kansas City. Mo.; } \\
\text { University of Pennsylvania, } \\
\text { Philadelphia }\end{array}$ \\
\hline 7 & VIR-7831 & $\begin{array}{c}\text { Plant-based } \\
\text { adjuvant vaccine }\end{array}$ & $\begin{array}{l}\text { Medicago; GSK; } \\
\text { Dynavax }\end{array}$ & Phase $2 / 3$ & Medicago \\
\hline 8 & $\begin{array}{l}\text { No name } \\
\text { announced }\end{array}$ & $\begin{array}{l}\text { Adenovirus-based } \\
\text { vaccine }\end{array}$ & $\begin{array}{l}\text { ImmunityBio; } \\
\text { NantKwest }\end{array}$ & Phase $2 / 3$ & NA \\
\hline 9 & UB-612 & $\begin{array}{l}\text { Multitope } \\
\text { peptide-based } \\
\text { vaccine }\end{array}$ & COVAXX & Phase $2 / 3$ & United Biomedical Inc. (UBI) \\
\hline 10 & $\begin{array}{l}\text { No name } \\
\text { announced }\end{array}$ & $\begin{array}{l}\text { Recombinant } \\
\text { protein vaccine }\end{array}$ & $\begin{array}{c}\text { Sanofi; } \\
\text { GlaxoSmithKline }\end{array}$ & Phase 2 & Various \\
\hline 11 & BNT162 & $\begin{array}{l}\text { mRNA-based } \\
\text { vaccine }\end{array}$ & Pfizer, BioNTech & Phase 1/2/3 & $\begin{array}{l}\text { Multiple study sites in Europe } \\
\text { North America and China }\end{array}$ \\
\hline 12 & Soberana 1 and 2 & $\begin{array}{c}\text { Monovalent/ } \\
\text { conjugate vaccine }\end{array}$ & $\begin{array}{c}\text { Finlay Institute of } \\
\text { Vaccines }\end{array}$ & Phase $1 / 2 / 3$ & Finlay Institute of Vaccines \\
\hline 13 & AdCLD-CoV19 & $\begin{array}{l}\text { Adenovirus-based } \\
\text { vaccine }\end{array}$ & Cellid; LG Chem & Phase $1 / 2 a$ & $\begin{array}{c}\text { Korea University Guro } \\
\text { Hospital }\end{array}$ \\
\hline 14 & Nanocovax & $\begin{array}{l}\text { Recombinant } \\
\text { vaccine (Spike } \\
\text { protein) }\end{array}$ & $\begin{array}{c}\text { Nanogen } \\
\text { Biopharmaceutical }\end{array}$ & Phase $1 / 2$ & $\begin{array}{l}\text { Military Medical Academy } \\
\text { (Vietnam) }\end{array}$ \\
\hline 15 & EuCorVac-19 & $\begin{array}{l}\text { nanoparticle } \\
\text { vaccine }\end{array}$ & EuBiologics & Phase $1 / 2$ & $\begin{array}{l}\text { Eunpyeong St. Mary's } \\
\text { Hospital }\end{array}$ \\
\hline 16 & $\begin{array}{c}\text { Mambisa (CIGB } \\
669)\end{array}$ & $\begin{array}{l}\text { Protein subunit } \\
\text { vaccine }\end{array}$ & $\begin{array}{l}\text { Center for Genetic } \\
\text { Engineering and } \\
\text { Biotechnology }\end{array}$ & Phase $1 / 2$ & $\begin{array}{l}\text { Center for Genetic } \\
\text { Engineering and } \\
\text { Biotechnology }\end{array}$ \\
\hline 17 & IIBR-100 & $\begin{array}{c}\text { Recombinant } \\
\text { vesicular stomatitis } \\
\text { virus (rVSV) } \\
\text { vaccine }\end{array}$ & $\begin{array}{l}\text { Israel Institute for } \\
\text { Biological Research }\end{array}$ & Phase $1 / 2$ & $\begin{array}{c}\text { Hadassah Medical Center; } \\
\text { Sheba Medical Center } \\
\text { Hospital }\end{array}$ \\
\hline 18 & $\begin{array}{l}\text { No name } \\
\text { announced }\end{array}$ & $\begin{array}{l}\text { SF9 cell vaccine } \\
\text { candidate }\end{array}$ & $\begin{array}{c}\text { West China } \\
\text { Hospital, Sichuan } \\
\text { University }\end{array}$ & Phase $1 / 2$ & $\begin{array}{c}\text { West China Hospital, Sichuan } \\
\text { University }\end{array}$ \\
\hline 19 & VLA2001 & Inactivated vaccine & $\begin{array}{l}\text { Valneva; National } \\
\text { Institute for Health } \\
\text { Research (NIHR) }\end{array}$ & Phase $1 / 2$ & Multiple NIHR testing sites \\
\hline 20 & $\begin{array}{l}\text { No name } \\
\text { announced }\end{array}$ & $\begin{array}{l}\text { Adjuvanted } \\
\text { protein subunit } \\
\text { vaccine }\end{array}$ & CEPI & Phase $1 / 2$ & NA \\
\hline
\end{tabular}


Table 5. Cont.

\begin{tabular}{|c|c|c|c|c|c|}
\hline S.No & Candidate Name & Vaccine Type & Sponsor/Developer & $\begin{array}{l}\text { Clinical Trial } \\
\text { Stage }\end{array}$ & Companies/Universities \\
\hline 21 & AG0301-COVID19 & DNA vaccine & AnGes, Inc. & Phase $1 / 2$ & $\begin{array}{c}\text { AnGes, Inc.; Japan Agency } \\
\text { for Medical Research and } \\
\text { Development }\end{array}$ \\
\hline 22 & GX-19N & DNA vaccine & Genexine & Phase $1 / 2$ & \\
\hline 23 & $\begin{array}{c}\text { ARCT-021 } \\
\text { (LUNAR-COV19) }\end{array}$ & $\begin{array}{l}\text { Self-replicating } \\
\text { RNA vaccine }\end{array}$ & $\begin{array}{c}\text { Arcturus } \\
\text { Therapeutics and } \\
\text { Duke-NUS Medical } \\
\text { School }\end{array}$ & Phase $1 / 2$ & $\begin{array}{l}\text { Duke-NUS Medical School, } \\
\text { Singapore }\end{array}$ \\
\hline 24 & $\begin{array}{l}\text { No name } \\
\text { announced }\end{array}$ & Inactivated vaccine & $\begin{array}{c}\text { Chinese Academy of } \\
\text { Medical Sciences, } \\
\text { Institute of Medical } \\
\text { Biology }\end{array}$ & Phase $1 / 2$ & $\begin{array}{l}\text { West China Second } \\
\text { University Hospital, Yunnan } \\
\text { Center for Disease Control } \\
\text { and Prevention }\end{array}$ \\
\hline 25 & $\begin{array}{l}\text { HDT-301 } \\
\text { (HGCO19) }\end{array}$ & RNA vaccine & $\begin{array}{c}\text { University of } \\
\text { Washington; } \\
\text { National Institutes of } \\
\text { Health Rocky } \\
\text { Mountain } \\
\text { Laboratories; HDT } \\
\text { Bio Corp; Gennova } \\
\text { Biopharmaceuticals }\end{array}$ & Phase $1 / 2$ & NA \\
\hline 26 & AV-COVID-19 & $\begin{array}{l}\text { Dendritic cell } \\
\text { vaccine }\end{array}$ & $\begin{array}{l}\text { Aivita Biomedical, } \\
\text { Inc. }\end{array}$ & Phase $1 b / 2$ & $\begin{array}{c}\text { Rumah Sakit Umum Pusat } \\
\text { DrKariadi }\end{array}$ \\
\hline 27 & PTX-COVID19-B & $\begin{array}{l}\text { mRNA-based } \\
\text { vaccine }\end{array}$ & $\begin{array}{l}\text { Providence } \\
\text { Therapeutics; } \\
\text { Canadian } \\
\text { government }\end{array}$ & Phase 1 & NA \\
\hline 28 & COVI-VAC & Intranasal vaccine & $\begin{array}{l}\text { Codagenix; Serum } \\
\text { Institute of India }\end{array}$ & Phase 1 & NA \\
\hline 29 & CORVax12 & $\begin{array}{l}\text { DNA vaccine } \\
\text { (plasmid) }\end{array}$ & $\begin{array}{l}\text { OncoSec; Providence } \\
\text { Cancer Institute }\end{array}$ & Phase 1 & $\begin{array}{c}\text { Providence Portland Medical } \\
\text { Center }\end{array}$ \\
\hline 30 & MVA-SARS-2-S & $\begin{array}{l}\text { Modified vaccinia } \\
\text { virus ankara } \\
\text { (MVA) vector } \\
\text { vaccine candidate }\end{array}$ & $\begin{array}{c}\text { Universitätsklinikum } \\
\text { Hamburg- } \\
\text { Eppendorf; German } \\
\text { Center for Infection } \\
\text { Research; Philipps } \\
\text { University Marburg } \\
\text { Medical Center; } \\
\text { Ludwig- } \\
\text { Maximilians- } \\
\text { University of } \\
\text { Munich }\end{array}$ & Phase 1 & $\begin{array}{l}\text { University Medical Center } \\
\text { Hamburg-Eppendorf }\end{array}$ \\
\hline 31 & $\mathrm{COH} 04 \mathrm{~S} 1$ & $\begin{array}{l}\text { Modified vaccinia } \\
\text { virus ankara } \\
\text { (MVA) vector } \\
\text { vaccine candidate }\end{array}$ & $\begin{array}{c}\text { City of Hope } \\
\text { Medical Center; } \\
\text { National Cancer } \\
\text { Institute }\end{array}$ & Phase 1 & City of Hope Medical Center \\
\hline 32 & pVAC & $\begin{array}{c}\text { Multi-peptide } \\
\text { vaccine candidate }\end{array}$ & $\begin{array}{l}\text { University Hospital } \\
\text { Tuebingen }\end{array}$ & Phase 1 & $\begin{array}{l}\text { University Hospital } \\
\text { Tuebingen }\end{array}$ \\
\hline 33 & AdimrSC-2f & $\begin{array}{l}\text { Protein subunit } \\
\text { vaccine }\end{array}$ & Adimmune & Phase 1 & Adimmune \\
\hline 34 & bacTRL-Spike & $\begin{array}{l}\text { Monovalent oral } \\
\text { vaccine } \\
\text { (bifidobacteria) }\end{array}$ & Symvivo & Phase 1 & Symvivo Corporation \\
\hline
\end{tabular}


Table 5. Cont.

\begin{tabular}{|c|c|c|c|c|c|}
\hline S.No & Candidate Name & Vaccine Type & Sponsor/Developer & $\begin{array}{l}\text { Clinical Trial } \\
\text { Stage }\end{array}$ & Companies/Universities \\
\hline 35 & COVAX-19 & $\begin{array}{l}\text { Monovalent } \\
\text { recombinant } \\
\text { protein vaccine }\end{array}$ & Vaxine Pty Ltd. & Phase 1 & Royal Adelaide Hospital \\
\hline 36 & $\begin{array}{c}\text { DelNS1-2019- } \\
\text { nCoV-RBD-OPT1 }\end{array}$ & $\begin{array}{l}\text { Replicating viral } \\
\text { vector }\end{array}$ & $\begin{array}{l}\text { Xiamen University, } \\
\text { Beijing Wantai } \\
\text { Biological Pharmacy }\end{array}$ & Phase 1 & $\begin{array}{c}\text { Jiangsu Provincial Centre For } \\
\text { Disease Control and } \\
\text { Prevention }\end{array}$ \\
\hline 37 & GRAd-COV2 & $\begin{array}{l}\text { Adenovirus-based } \\
\text { vaccine }\end{array}$ & $\begin{array}{c}\text { ReiThera; Leukocare; } \\
\text { Univercells }\end{array}$ & Phase 1 & $\begin{array}{c}\text { Lazzaro Spallanzani National } \\
\text { Institute for Infectious } \\
\text { Diseases }\end{array}$ \\
\hline 38 & UQ-CSL V451 & $\begin{array}{l}\text { Protein subunit } \\
\text { vaccine }\end{array}$ & $\begin{array}{c}\text { CSL; The University } \\
\text { of Queensland }\end{array}$ & Phase 1 & NA \\
\hline 39 & SCB-2019 & $\begin{array}{l}\text { Protein subunit } \\
\text { vaccine }\end{array}$ & $\begin{array}{c}\text { GlaxoSmithKline, } \\
\text { Sanofi, Clover } \\
\text { Biopharmaceuticals, } \\
\text { Dynavax and } \\
\text { Xiamen Innovax; } \\
\text { CEPI }\end{array}$ & Phase 1 & $\begin{array}{c}\text { Linear Clinical Research } \\
\text { (Australia) }\end{array}$ \\
\hline
\end{tabular}

\begin{tabular}{|c|c|c|c|c|c|}
\hline 40 & VXA-CoV2-1 & $\begin{array}{l}\text { Recombinant } \\
\text { vaccine } \\
\text { (adenovirus type } 5 \\
\text { vector) }\end{array}$ & Vaxart & Phase 1 & Vaxart \\
\hline 41 & AdCOVID & Intranasal vaccine & Altimmune & Phase 1 & $\begin{array}{c}\text { University of Alabama at } \\
\text { Birmingham }\end{array}$ \\
\hline 42 & AAVCOVID & $\begin{array}{l}\text { Gene-based } \\
\text { vaccine }\end{array}$ & $\begin{array}{c}\text { Massachusetts Eye } \\
\text { and Ear; } \\
\text { Massachusetts } \\
\text { General Hospital; } \\
\text { University of } \\
\text { Pennsylvania }\end{array}$ & Pre-clinical & NA \\
\hline 43 & $\begin{array}{l}\text { ChAd-SARS-CoV- } \\
2-S\end{array}$ & $\begin{array}{l}\text { Adenovirus-based } \\
\text { vaccine }\end{array}$ & $\begin{array}{l}\text { Washington } \\
\text { University School of } \\
\text { Medicine in St. Louis }\end{array}$ & Pre-clinical & $\begin{array}{l}\text { Washington University } \\
\text { School of Medicine in St. } \\
\text { Louis }\end{array}$ \\
\hline 44 & HaloVax & $\begin{array}{l}\text { Self-assembling } \\
\text { vaccine }\end{array}$ & $\begin{array}{l}\text { Voltron Therapeutics, } \\
\text { Inc.; Hoth } \\
\text { Therapeutics, Inc. }\end{array}$ & Pre-clinical & $\begin{array}{l}\text { MGH Vaccine and } \\
\text { Immunotherapy Center }\end{array}$ \\
\hline 45 & LineaDNA & DNA vaccine & Takis Biotech & Pre-clinical & Takis Biotech \\
\hline 46 & MRT5500 & $\begin{array}{l}\text { mRNA-based } \\
\text { vaccine }\end{array}$ & Sanofi, Translate Bio & Pre-clinical & NA \\
\hline 47 & $\begin{array}{l}\text { No name } \\
\text { announced }\end{array}$ & $\begin{array}{l}\text { Ii-Key peptide } \\
\text { COVID-19 vaccine }\end{array}$ & $\begin{array}{c}\text { Generex } \\
\text { Biotechnology }\end{array}$ & Pre-clinical & Generex \\
\hline 48 & $\begin{array}{l}\text { No name } \\
\text { announced }\end{array}$ & $\begin{array}{l}\text { Protein subunit } \\
\text { vaccine }\end{array}$ & $\begin{array}{c}\text { University of } \\
\text { Saskatchewan } \\
\text { Vaccine and } \\
\text { Infectious Disease } \\
\text { Organization- } \\
\text { International Vaccine } \\
\text { Centre }\end{array}$ & Pre-clinical & $\begin{array}{l}\text { University of Saskatchewan } \\
\text { Vaccine and Infectious } \\
\text { Disease } \\
\text { Organization-International } \\
\text { Vaccine Centre }\end{array}$ \\
\hline 49 & $\begin{array}{l}\text { No name } \\
\text { announced }\end{array}$ & $\begin{array}{l}\text { mRNA-based } \\
\text { vaccine }\end{array}$ & $\begin{array}{l}\text { Chulalongkorn } \\
\text { University's Center } \\
\text { of Excellence in } \\
\text { Vaccine Research } \\
\text { and Development }\end{array}$ & Pre-clinical & NA \\
\hline
\end{tabular}


Table 5. Cont.

\begin{tabular}{|c|c|c|c|c|c|}
\hline S.No & Candidate Name & Vaccine Type & Sponsor/Developer & $\begin{array}{l}\text { Clinical Trial } \\
\text { Stage }\end{array}$ & Companies/Universities \\
\hline 50 & $\begin{array}{l}\text { No name } \\
\text { announced }\end{array}$ & $\begin{array}{l}\text { gp96-based } \\
\text { vaccine }\end{array}$ & Heat Biologics & Pre-clinical & $\begin{array}{l}\text { University of Miami Miller } \\
\text { School of Medicine }\end{array}$ \\
\hline 51 & $\begin{array}{l}\text { No name } \\
\text { announced }\end{array}$ & Inactivated vaccine & $\begin{array}{l}\text { Shenzhen Kangtai } \\
\text { Biological Products }\end{array}$ & Pre-clinical & NA \\
\hline 52 & PittCoVacc & $\begin{array}{c}\text { Recombinant } \\
\text { protein subunit } \\
\text { vaccine (delivered } \\
\text { through } \\
\text { microneedle array) }\end{array}$ & $\begin{array}{l}\text { UPMC/University } \\
\text { of Pittsburgh School } \\
\text { of Medicine }\end{array}$ & Pre-clinical & University of Pittsburgh \\
\hline 53 & T-COVIDTM & Intranasal vaccine & Altimmune & Pre-clinical & NA \\
\hline 54 & LNP-nCoVsaRNA & $\begin{array}{l}\text { Self-amplifying } \\
\text { RNA vaccine }\end{array}$ & $\begin{array}{l}\text { Imperial College } \\
\text { London }\end{array}$ & $\begin{array}{l}\text { No longer being } \\
\text { studied }\end{array}$ & Imperial College London \\
\hline 55 & V590 & $\begin{array}{c}\text { Recombinant } \\
\text { vaccine (vesicular } \\
\text { stomatitis virus) }\end{array}$ & Merck; IAVI & $\begin{array}{l}\text { No longer being } \\
\text { studied }\end{array}$ & NA \\
\hline 56 & V591 & $\begin{array}{l}\text { Measles vector } \\
\text { vaccine }\end{array}$ & $\begin{array}{c}\text { University of } \\
\text { Pittsburgh's Center } \\
\text { for Vaccine Research }\end{array}$ & $\begin{array}{l}\text { No longer being } \\
\text { studied }\end{array}$ & $\begin{array}{c}\text { University of Pittsburgh; } \\
\text { Themis Biosciences; Institut } \\
\text { Pasteur }\end{array}$ \\
\hline
\end{tabular}

\section{Other Promising Therapeutics}

In China, the medical researchers collected plasma from COVID-19 recovered patients and re-infused it into clinically ill patients who showed complete recovery from COVID-19 disease with good pulmonary compliance. Recently, CR3022 (monoclonal antibody) binding with the spike RBD of SARS-CoV-2 has also been identified, and this is probably due to the antibody's epitope not overlapping with the divergent ACE2 receptor-binding motif. With the pieces of the available evidence on CR3022 (monoclonal antibody), it can be plausibly used as a therapeutic to treat COVID-19 [175]. Recently, Remdesivir, lopinavir, emetine, and homoharringtonine have also reported inhibiting SARS-CoV-2 replication in vitro [176]. Further, the sensitivity of SARS-CoV-2 to recombinant human interferons $\alpha$ and $\beta(\operatorname{IFN} \alpha / \beta)$ has also been observed. Treatment with IFN- $\alpha$ or IFN- $\beta$ at a concentration of 50 international units (IU) per milliliter reduces the viral titers by $3.4 \log$ or over $4 \log$, respectively, in Vero cells. The noted EC50 of IFN- $\alpha$ and IFN- $\beta$ treatment is $1.35 \mathrm{IU} / \mathrm{mL}$ and $0.76 \mathrm{IU} / \mathrm{mL}$, respectively, in Vero cells. These results suggest the higher sensitivity of SARS-CoV-2 compared to other human pathogenic viruses, including SARS-CoV. Overall, this study shows the potential efficacy of human type-I IFN in suppressing SARS-CoV-2 infection, a finding which could inform future treatment options for COVID-19 [177]. Further, usingneutralizing antibodies against SARS-CoV-2 (anti-SARS-CoVnAbs) can be an alternative approach to prevent SARS-CoV-2 infection [178].

The utilization of nucleotide analogs can be another potential approach to treat COVID-19. These nucleotide analogs have the potential to evade the exonuclease activity of the virus. In this context, it is noteworthy that the prodrugs of five of these nucleotide analogs (Cidofovir, Abacavir, Valganciclovir/Ganciclovir, Stavudine, and Entecavir) are FDA-approved medications for treating other viral infections with well-established safety profiles. To reiterate, following the demonstration of the inhibiting potency of viral replication in cell culture, the candidature molecules are subjected to being evaluated as potential therapies for COVID-19 [179]. Further, type 1 interferons can be more helpful in treating COVID-19. The experience and knowledge inferred from the IFN-I treatment against SARS-CoV and MERS-CoV prove valuable in the selection of potential treatments against SARS-CoV-2 [180]. 
Interestingly, Ivermectin, a FDA-approved anti-parasitic agent, has previously showed broad-spectrum antiviral activity in vitro, as an inhibitor of the causative virus (SARS-CoV2), with a single addition to Vero-hSLAM cells $2 \mathrm{~h}$ post-infection with SARS-CoV-2 able to effect $\sim 5000$-fold reduction in viral RNA at $48 \mathrm{~h}$. Therefore, this agent warrants further investigation to perquisite humans [166].

Due to the drastic improvement in the field of molecular biology and translational science, cellular therapy has emerged as a potential option for combating COVID-19 [181]. Cellular therapy deals with the usage of autologous or allogenic pooled conditioned stored cells to treat the disease and to regenerate the damaged cells, tissues, or organs. Researchers have thrown the limelight on the usage of various cells like bone marrow mesenchymal stem cells, adipose tissue-derived mesenchymal stem cells, and placentalderived mesenchymal stem cells (MSCs) to curb COVID-19 pneumonia. A total of 53 clinical trials have been in the recruiting status and are ongoing. The results of these trials are awaited (ClinicalTrials.Gov). Despite the advantage of regenerating the damaged pulmonary epithelium, MSCs have quite a list of challenges when administering to patients with COVID-19. The challenges in the usage of cellular therapy are isolation, harvesting, and characterization of cells, preparation protocols, route of administration, dose, and frequency of treatment, immune privilege nature, and the expected outcome of the cells that have been transfused. Outweighing the challenges, cellular therapy has a ray of hope to curb COVID-19 pneumonia.

The natural metabolites of the different chemical agents present a ray of hope, and promising data on virtual molecular docking hasbeen enumerated in Table 6. Despite the distinct molecular structure, several chemical agents (flavanones, flavonols, alkaloids, fatty acids, quinones, terpenes, and steroids) possess similar docking forces to the repurposed drugs (e.g., Remdesivir and Chloroquine) with proteins/signals/receptors involved in SARS-CoV-2 replication, including ACE2, 3CLpro, and TMPRSS-2. It can be inferred from the docking evaluation that inhibitors of ACE2 retard the binding capacity of SARS-CoV-2 and arrest the viral entry into pulmonary epithelium $[182,183]$. Considering the blockade of SARS-CoV-2 infection through the ACE2 receptor, the lowest affinity was possessed by Flavolignan silybin. Rahma et al. [184] suggested 12 natural metabolites having binding energy with TPMRSS2 ranging from -11.06 to $-14.69 \mathrm{kcal}$ mol. The search for TMPRSS2 inhibitors is lowered within the major replication proteins, despite that molecular docking shows another strategy to be investigated for treating COVID-19 [133]. Notably, the role of TMPRSS2 in inoculation and replication of influenza virus, cancer, and SARS-CoV-1 [185] has been well-documented. Besides, researchers are more promptly searchingfor strategies to target the inhibition of the main protein (3CLpro) of SARS-CoV-2, as it could prevent the inoculation of the virus in the host [186-188]. Although the 3CLpro is an enzyme specific to the virus, the one within SARS-CoV-2 has a large structural similarity with the one present in SARS-CoV-1 (96.08\%) [182]. In silico analysis demonstrated that the terpenoids Bonducellpin D and Caesalmin B and the flavonoid 5,7-dimethoxy flavanone-40O-b-d-glucopyranoside have binding affinities with 3CLpro of SARS-CoV-1, SARS-CoV-2, and MERS-CoV ranging from -8 to $-11 \mathrm{kcal} \mathrm{mol}^{-1}$, an outstanding value compared to repurposed drugs (Table 6). 
Table 6. Recently evaluated natural metabolites against COVID-19 by virtual docking.

\begin{tabular}{|c|c|c|c|}
\hline Target/Binding Site & Natural Products/Metabolites & Binding Energy (kcal mol-1) & Reference \\
\hline \multirow{40}{*}{ ACE2 } & Zhebeininoside & -6.8 & \multirow{5}{*}{ [189] } \\
\hline & Verdine & -6.6 & \\
\hline & Pseudojervine & -6.8 & \\
\hline & Imperialine-3-b-D-glucoside & -7.1 & \\
\hline & Hupehemonside & -7.1 & \\
\hline & Nobiletin & -5.42 & \multirow{6}{*}{ [190] } \\
\hline & Neohesperidin & -3.78 & \\
\hline & Hesperetin & -6.09 & \\
\hline & Hesperidin & -4.21 & \\
\hline & Naringenin & -6.05 & \\
\hline & Narigin & -6.85 & \\
\hline & Chloroquine & -8.019 & \multirow{10}{*}{ [191] } \\
\hline & Philligenin & -7.807 & \\
\hline & Hinokinin & -7.11 & \\
\hline & Withaferin A & -9.631 & \\
\hline & Quercetin & -8.664 & \\
\hline & Isoaloresin & -7.835 & \\
\hline & Aloin & -8.383 & \\
\hline & Corydine & -6.041 & \\
\hline & Tetrahydrocurcumin & -8.009 & \\
\hline & Silybin & -10.572 & \\
\hline & Isoquercitrin & -7.8 & \multirow{16}{*}{ [192] } \\
\hline & Afzelin & -7.1 & \\
\hline & Oriciacridone F & -6.7 & \\
\hline & Remdesivir & -7.8 & \\
\hline & Cassameridin & -8.1 & \\
\hline & (-)-Asperlicin C & -9.5 & \\
\hline & Kaempferol & -7.2 & \\
\hline & Apigenin & -7.1 & \\
\hline & Myricitrin & -7.1 & \\
\hline & Vitetrifolin D & -7.3 & \\
\hline & Lactucopicrin & -8.3 & \\
\hline & Lactucopicrin 15-oxalate & -8.3 & \\
\hline & Taiwanhomoflavone A & -7.6 & \\
\hline & Epicatechin- $(4 b, 8)$-epicatechin- $(4 b, 6)$-catechin & -8.2 & \\
\hline & Epicatechin-4-epigallocatechin & -7.2 & \\
\hline & Quercetin 3-glucosyl-(1,4)-rhamnoside & -6.5 & \\
\hline & Epicatechin-gallate & -6.27 & [193] \\
\hline & $\alpha$-Copaene & -20.08 & [194] \\
\hline & (E)- $\beta$-Farnesene & -27.56 & [194] \\
\hline
\end{tabular}


Table 6. Cont.

\begin{tabular}{|c|c|c|c|}
\hline Target/Binding Site & Natural Products/Metabolites & Binding Energy $\left(\mathrm{kcal} \mathrm{mol}^{-1}\right)$ & Reference \\
\hline \multirow{34}{*}{ 3CLpro } & Gingerol & -5.38 & \multirow{7}{*}{ [193] } \\
\hline & Zingerol & -5.4 & \\
\hline & Apigenin-7-glucoside & -7.83 & \\
\hline & Quercetin & -8.47 & \\
\hline & Kaempferol & -8.58 & \\
\hline & Lopinavir & -9.41 & \\
\hline & Nelfinavir & -10.74 & \\
\hline & Sugiol & -6.04 & \multirow{4}{*}{ [195] } \\
\hline & N-cis-feruloyltyramine & -6.25 & \\
\hline & Cryptotanshinone & -6.23 & \\
\hline & Betulinic acid & -4.23 & \\
\hline & Amaranthin & -18.14 & \multirow{4}{*}{ [196] } \\
\hline & Methyl rosmarinate & -20.62 & \\
\hline & $\begin{array}{c}5,7,3 \text { ', 4'-tetrahydroxy-2'-(3,3-dimethylallyl) } \\
\text { isoflavone }\end{array}$ & -29.57 & \\
\hline & Mirycitrin & 22.13 & \\
\hline & Zeylanone & -9.12 & \multirow{3}{*}{ [197] } \\
\hline & Glabrolide & -9.16 & \\
\hline & Amentoflavone & -9.28 & \\
\hline & Isoquercitrin & -8.2 & \multirow{16}{*}{ [192] } \\
\hline & Afzelin & -8.8 & \\
\hline & Oriciacridone F & -9.1 & \\
\hline & Remdesivir & -8.2 & \\
\hline & Cassameridin & -9.3 & \\
\hline & Kaempferol & -7.8 & \\
\hline & (-)-Asperlicin C & -9.7 & \\
\hline & Apigenin & -7.8 & \\
\hline & Myricitrin & -8.9 & \\
\hline & Vitetrifolin D & -7.6 & \\
\hline & Lactucopicrin 15-oxalate & -8.2 & \\
\hline & Lactucopicrin & -7.8 & \\
\hline & Quercetin 3-glucosyl-(1,4)-rhamnoside & -9.9 & \\
\hline & Epicatechin-(4',8)-epigallocatechin & -10 & \\
\hline & Epicatechin-(4b,8)-epicatechin- $(4 b, 6)$-catechin & -10.6 & \\
\hline & Taiwanhomoflavone A & -9.6 & \\
\hline \multirow{5}{*}{ TMPRSS2 } & Isogemichalcone B & -13.07 & \multirow{5}{*}{ [184] } \\
\hline & Microcarpin & -13.31 & \\
\hline & Durumolide K & -13.92 & \\
\hline & Dictyosphaeric acid A & -14.02 & \\
\hline & Geniposide & -14.69 & \\
\hline
\end{tabular}


Table 6. Cont.

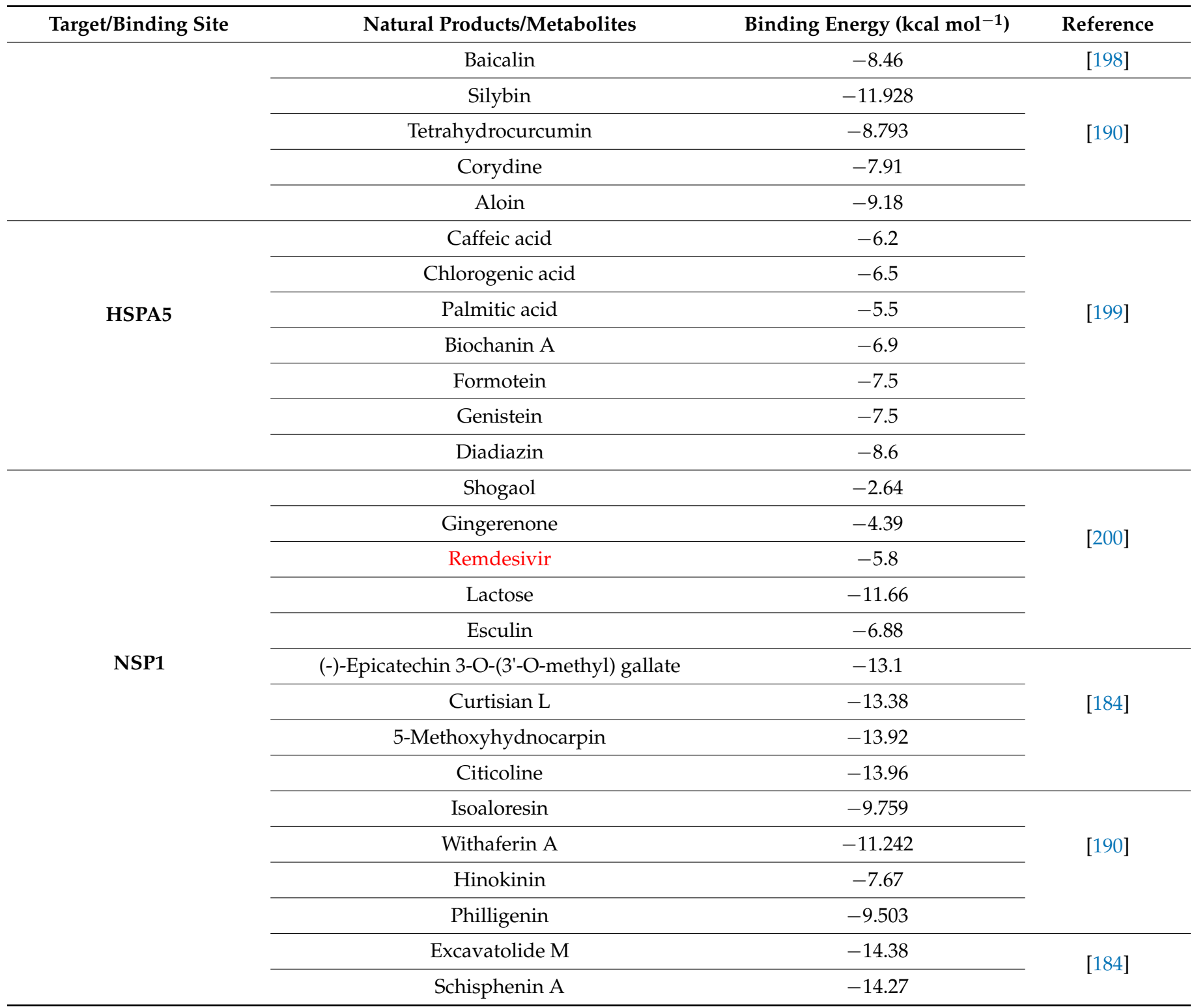

Red color: a repurposed drug used as control.

\section{Obstacles to Research on COVID-19 Pathogenesis}

Animal models serve a critical role in unveiling pathogenicity mechanisms of the virus, from the entrance to the transmission, and targeting therapeutic strategies. Earlier, to check the replication of SARS-CoV-2, symptoms of serious infections were depicted by different animal models [201]. In small animals, MERS-CoV pathogenesis was not observed in contrast to SARS-CoV-2. As a result of the non-compatibility of the DPP4 receptor, mice are not at risk of infection with MERS-coronavirus [202]. The infectious pathogenicity of SARS-CoV-2 can be determined by the animal models as used in SARS-CoV-2 since both the viruses share $80 \%$ of the genomes and recognize ACE2 receptors. Hamsters that have been genetically modified with CRISPR or TALEN or other small animals can be used for studying the novel coronaviruses' pathogenicity. Replication of SARS-CoV-2 has been reported as a cause for severe ailments in rats (f344), wherein at spike glycoprotein, a mutation was revealed by the sequence analysis [203]. Therefore, it can emerge as a suitable alternate option for the development of spike glycoprotein targeting therapeutics 
against novel coronaviruses. Clinical isolates and mice models were used recently for the development of a therapeutic strategy against COVID-19 induced by SARS-CoV-2 [111,152]. Artificial Intelligence prediction has also been used in a similar study for investigating the drug's inhibitory role against SARS-CoV-2 [153]. Randomized clinical trials were also conducted on patients suffering from SARS-CoV-2 [147,151,152]. The investigation into the invivo mechanisms relevant to the pathogenesis of COVID-19 mandates the global collaboration of scientists for designing an appropriate model.

\section{Conclusions}

The sudden sprouting of COVID-19 cases across the globe has questioned the solidarity of the medical fraternity. Apart from lungs, viral infections-mediated inflammatory state and immonumodulation may have potentially adverse impacts on several other organs/organ systems, too [204,205]. The sudden outset of this viral infection has brought people into captivity across the nations. The day-to-day altering trends in symptomatology and presentation have pacified the molecular research and developmental sciences to come up with safer and effective therapeutic agents and vaccines. To date, we are comprehending and battling this pandemic with no proven therapeutics. The need of the hour is to consider a holistic approach and render supportive care, as per the presenting severity of the case. While combating a pandemic, it is of utmost importance for health care professionals to keep themselves updated with the current and emerging therapeutic trends for treating the disease with greater effectiveness [206-210]. A multidisciplinary team must mitigate the secondary waves of the pandemic with all the necessary precautions. At the same time, it is equally important to optimize novel ideology of cellular therapy protocols in adjunct to the development of vaccines, as these have the potential to prove as the positive shades of a rainbow amidst the storm of COVID-19 pandemic. Further research on the definitive management protocols by conducting randomized controlled trials is greatly needed for the hour because safety and efficacy parameters need to be concretely investigated.

Author Contributions: N.K.J. designed and wrote this review with input from all other authors who contributed to studies that led to the view presented in this manuscript. All authors have read and agreed to the published version of the manuscript.

Funding: This research received no external funding.

Conflicts of Interest: The authors declare no conflict of interest.

\section{References}

1. Wang, C.; Horby, P.W.; Hayden, F.G.; Gao, G.F. A novel coronavirus outbreak of global health concern. Lancet 2020, 395, 470-473. [CrossRef]

2. Li, H.; Liu, S.-M.; Yu, X.-H.; Tang, S.-L.; Tang, C.-K. Coronavirus disease 2019 (COVID-19): Current status and future perspectives. Int. J. Antimicrob. Agents 2020, 55, 105951. [CrossRef]

3. Guo, Y.-R.; Cao, Q.-D.; Hong, Z.-S.; Tan, Y.-Y.; Chen, S.-D.; Jin, H.-J.; Tan, K.-S.; Wang, D.-Y.; Yan, Y. The origin, transmission and clinical therapies on coronavirus disease 2019 (COVID-19) outbreak-An update on the status. Mil. Med Res. 2020, 7, 1-10. [CrossRef]

4. Zheng, Y.-Y.; Ma, Y.-T.; Zhang, J.-Y.; Xie, X. COVID-19 and the cardiovascular system. Nat. Rev. Cardiol. 2020, 17, 259-260. [CrossRef]

5. Cinatl, J.; Morgenstern, B.; Bauer, G.; Chandra, P.; Rabenau, H.; Doerr, H. Treatment of SARS with human interferons. Lancet 2003, 362, 293-294. [CrossRef]

6. Florindo, H.F.; Kleiner, R.; Vaskovich-Koubi, D.; Acúrcio, R.C.; Carreira, B.; Yeini, E.; Tiram, G.; Liubomirski, Y.; Satchi-Fainaro, R. Immune-mediated approaches against COVID-19. Nat. Nanotechnol. 2020, 15, 630-645. [CrossRef]

7. Chan, J.F.; Chan, K.-H.; Kao, R.Y.; To, K.K.; Zheng, B.-J.; Li, C.P.; Li, P.T.; Dai, J.; Mok, F.K.; Chen, H.; et al. Broad-spectrum antivirals for the emerging Middle East respiratory syndrome coronavirus. J. Infect. 2013, 67, 606-616. [CrossRef]

8. Cheng, K.-W.; Cheng, S.-C.; Chen, W.-Y.; Lin, M.-H.; Chuang, S.-J.; Cheng, I.-H.; Sun, C.-Y.; Chou, C.-Y. Thiopurine analogs and mycophenolic acid synergistically inhibit the papain-like protease of Middle East respiratory syndrome coronavirus. Antivir. Res. 2015, 115, 9-16. [CrossRef]

9. Wang, Y.; Sun, Y.; Wu, A.; Xu, S.; Pan, R.; Zeng, C.; Jin, X.; Ge, X.; Shi, Z.; Ahola, T.; et al. Coronavirus nsp10/nsp16 methyltransferase can be targeted by nsp10-derived peptide in vitro and in vivo to reduce replication and pathogenesis. J. Virol. 2015, 89, 8416-8427. [CrossRef] 
10. Mair-Jenkins, J.; Saavedra-Campos, M.; Baillie, J.K.; Cleary, P.; Khaw, F.M.; Lim, W.S.; Makki, S.; Rooney, K.D.; Nguyen-Van-Tam, J.S.; Beck, C.R. The effectiveness of convalescent plasma and hyperimmune immunoglobulin for the treatment of severe acute respiratory infections of viral etiology: A systematic review and exploratory meta-analysis. J. Infect. Dis. 2015, 211, 80-90. [CrossRef]

11. Graham, R.L.; Donaldson, E.F.; Baric, R.S. A decade after SARS: Strategies for controlling emerging coronaviruses. Nat. Rev. Microbiol. 2013, 11, 836-848. [CrossRef]

12. De Wit, E.; Feldmann, F.; Cronin, J.; Jordan, R.; Okumura, A.; Thomas, T.; Scott, D.; Cihlar, T.; Feldmann, H. Prophylactic and therapeutic remdesivir (GS-5734) treatment in the rhesus macaque model of MERS-CoV infection. Proc. Natl. Acad. Sci. USA 2020, 3, 2019-2208. [CrossRef]

13. Burrell, C.J.; Howard, C.R.; Murphy, F.A. Fenner and White's Medical Virology; Elsevier BV: Amsterdam, The Netherlands, 2017.

14. Burrell, A.J.; Pellegrini, B.; Salimi, F.; Begum, H.; Broadley, T.; Campbell, L.T.; Cheng, A.C.; Cheung, W.; Cooper, D.J.; Earnest, A.; et al. Outcomes for patients with COVID-19 admitted to Australian intensive care units during the first four months of the pandemic. Med. J. Aust. 2021, 214, 23-30. [CrossRef]

15. Zhou, P.; Yang, X.L.; Wang, X.G.; Hu, B.; Zhang, L.; Zhang, W.; Si, H.R.; Zhu, Y.; Li, B.; Huang, C.L.; et al. A pneumonia outbreak associated with a new coronavirus of probable bat origin. Nature 2020, 579, 270-273. [CrossRef]

16. Hughes, J.; Wilson, M.; Luby, S.; Gurley, E.; Hossain, M. Transmission of human infection with Nipah virus. Clin. Infect. Dis. 2009, $49,1743-1748$.

17. Kan, B.; Wang, M.; Jing, H.; Xu, H.; Jiang, X.; Yan, M.; Liang, W.; Zheng, H.; Wan, K.; Liu, Q.; et al. Molecular Evolution Analysis and Geographic Investigation of Severe Acute Respiratory Syndrome Coronavirus-Like Virus in Palm Civets at an Animal Market and on Farms. J. Virol. 2005, 79, 11892-11900. [CrossRef]

18. Zheng, B.J.; Guan, Y.; Wong, K.H.; Zhou, J.; Wong, K.L.; Young, B.W.Y.; Lu, L.W.; Lee, S.S. SARS-related Virus Predating SARS Outbreak, Hong Kong. Emerg. Infect. Dis. 2004, 10, 176-178. [CrossRef]

19. Shi, Z.; Hu, Z. A review of studies on animal reservoirs of the SARS coronavirus. Virus Res. 2008, 133, 74-87. [CrossRef]

20. Memish, Z.A.; Zumla, A.I.; Al-Hakeem, R.F.; Al-Rabeeah, A.A.; Stephens, G.M. Family Cluster of Middle East Respiratory Syndrome Coronavirus Infections. N. Engl. J. Med. 2013, 368, 2487-2494. [CrossRef]

21. Annan, A.; Baldwin, H.J.; Corman, V.M.; Klose, S.M.; Owusu, M.; Nkrumah, E.E.; Badu, E.K.; Anti, P.; Agbenyega, O.; Meyer, B. Human betacorona virus 2c EMC/2012-related viruses in bats, Ghana and Europe. Emerg Infect Dis. 2013, 19, 456. [CrossRef] [PubMed]

22. Huynh, J.; Li, S.; Yount, B.; Smith, A.; Sturges, L.; Olsen, J.C.; Nagel, J.; Johnson, J.B.; Agnihothram, S.; Gates, J.E.; et al. Evidence Supporting a Zoonotic Origin of Human Coronavirus Strain NL63. J. Virol. 2012, 86, 12816-12825. [CrossRef]

23. Lau, S.K.P.; Li, K.S.M.; Tsang, A.K.L.; Lam, C.S.F.; Ahmed, S.; Chen, H.; Chan, K.-H.; Woo, P.C.Y.; Yuen, K.-Y. Genetic Characterization of Betacoronavirus Lineage C Viruses in Bats Reveals Marked Sequence Divergence in the Spike Protein of Pipistrellus Bat Coronavirus HKU5 in Japanese Pipistrelle: Implications for the Origin of the Novel Middle East Respiratory Syndrome Coronavirus. J. Virol. 2013, 87, 8638-8650. [CrossRef] [PubMed]

24. Chan, J.F.-W.; Kok, K.-H.; Zhu, Z.; Chu, H.; To, K.K.-W.; Yuan, S.; Yuen, K.-Y. Genomic characterization of the 2019 novel human-pathogenic coronavirus isolated from a patient with atypical pneumonia after visiting Wuhan. Emerg. Microbes Infect. 2020, 9, 221-236. [CrossRef]

25. Lu, H.; Stratton, C.W.; Tang, Y. Outbreak of pneumonia of unknown etiology in Wuhan, China: The mystery and the miracle. J. Med. Virol. 2020, 92, 401-402. [CrossRef]

26. Chan, J.F.-W.; Yuan, S.; Kok, K.-H.; To, K.K.-W.; Chu, H.; Yang, J.; Xing, F.; Liu, J.; Yip, C.C.-Y.; Poon, R.W.-S.; et al. A familial cluster of pneumonia associated with the 2019 novel coronavirus indicating person-to-person transmission: A study of a family cluster. Lancet 2020, 395, 514-523. [CrossRef]

27. Fan, Y.; Zhao, K.; Shi, Z.-L.; Zhou, P. Bat Coronaviruses in China. Viruses 2019, 11, 210. [CrossRef] [PubMed]

28. Mahase, E. China coronavirus: What do we know so far? BMJ 2020, 368, m308. [CrossRef]

29. Hui, D.S.; Azhar, E.I.; Madani, T.A.; Ntoumi, F.; Kock, R.; Dar, O.; Ippolito, G.; Mchugh, T.D.; Memish, Z.A.; Drosten, C.; et al. The continuing 2019-nCoV epidemic threat of novel coronaviruses to global health-The latest 2019 novel coronavirus outbreak in Wuhan, China. Int. J. Infect. Dis. 2020, 91, 264-266. [CrossRef]

30. Rodriguez-Morales, A.J.; Bonilla-Aldana, D.K.; Balbin-Ramon, G.J.; Rabaan, A.A.; Sah, R.; Paniz-Mondolfi, A.; Pagliano, P.; Esposito, S. History is repeating itself: Probable zoonotic spillover as the cause of the 2019 novel coronavirus epidemic. Infez. Med. 2020, 28, 3-5.

31. Xu, X.-W.; Wu, X.-X.; Jiang, X.-G.; Xu, K.-J.; Ying, L.-J.; Ma, C.-L.; Li, S.-B.; Wang, H.-Y.; Zhang, S.; Gao, H.-N.; et al. Clinical findings in a group of patients infected with the 2019 novel coronavirus (SARS-Cov-2) outside of Wuhan, China: Retrospective case series. BMJ 2020, 368, m606. [CrossRef]

32. Ison, M.G.; Hirsch, H.H. Community-acquired respiratory viruses in transplant patients: Diversity, impact, unmet clinicalneeds. Clin. Microbiol. Rev. 2019, 32, e00042-19.

33. Kramer, A.; Schwebke, I.; Kampf, G. How long do nosocomial pathogens persist on inanimate surfaces? A systematic review. BMC Infect. Dis. 2006, 6, 130. [CrossRef]

34. Kampf, G.; Todt, D.; Pfaender, S.; Steinmann, E. Persistence of coronaviruses on inanimate surfaces and their inactivation with biocidal agents. J. Hosp. Infect. 2020, 104, 246-251. [CrossRef] 
35. Rothe, C.; Schunk, M.; Sothmann, P.; Bretzel, G.; Froeschl, G.; Wallrauch, C.; Zimmer, T.; Thiel, V.; Janke, C.; Guggemos, W. Transmission of 2019-nCoV infection from an asymptomatic contact in Germany. N. Engl. J. Med. 2020, 382, 970-971. [CrossRef]

36. Kupferschmidt, K. Study claiming new coronavirus can be transmitted by people without symptoms was flawed. Science $\mathbf{2 0 2 0}$. [CrossRef]

37. Bai, Y.; Yao, L.; Wei, T.; Tian, F.; Jin, D.Y.; Chen, L.; Wang, M. Presumed Asymptomatic Carrier Transmission of COVID-19. JAMA 2020, 323, 1406-1407. [CrossRef]

38. Huang, C.; Wang, Y.; Li, X.; Ren, L.; Zhao, J.; Hu, Y.; Zhang, L.; Fan, G.; Xu, J.; Gu, X. Clinical features of patients infected with 2019 novel coronavirus in Wuhan, China. Lancet 2020, 395, 497-506. [CrossRef]

39. Chu, D.K.W.; Pan, Y.; Cheng, S.M.S.; Hui, K.P.Y.; Krishnan, P.; Liu, Y.; Ng, D.Y.M.; Wan, C.K.C.; Yang, P.; Wang, Q.; et al. Molecular Diagnosis of a Novel Coronavirus (2019-nCoV) Causing an Outbreak of Pneumonia. Clin. Chem. 2020, 66, 549-555. [CrossRef]

40. Li, Q.; Guan, X.; Wu, P.; Qun, L.; Xuhua, G.; Peng, W.; Xiaoye, W.; Lei, Z.; Yeqing, T.; Ruiqi, R.; et al. Early transmission dynamics in Wuhan, China, of Novel Coronavirus_Infected pneumonia. N. Engl. J. Med. 2020, 382, 1199-1207. [CrossRef] [PubMed]

41. WHO (World Health Organization). Clinical Management of Severe Acute Respiratory Infection When Novel Coronavirus (2019-nCoV) Infection Is Suspected: Interim Guidance; WHO: New York, NY, USA, 2020; pp. 1-19.

42. Bauch, C.; Oraby, T. Assessing the pandemic potential of MERS-CoV. Lancet 2013, 382, 662-664. [CrossRef]

43. Riley, S.; Fraser, C.; Donnelly, C.A.; Ghani, A.C.; Abu-Raddad, L.J.; Hedley, A.J.; Leung, G.M.; Ho, L.-M.; Lam, T.-H.; Thach, T.Q.; et al. Transmission Dynamics of the Etiological Agent of SARS in Hong Kong: Impact of Public Health Interventions. Science 2003, 300, 1961-1966. [CrossRef]

44. Yang, Y.; Sugimoto, J.D.; Halloran, M.E.; Basta, N.E.; Chao, D.L.; Matrajt, L.; Potter, G.; Kenah, E.; Longini, I.M. The Transmissibility and Control of Pandemic Influenza A (H1N1) Virus. Science 2009, 326, 729-733. [CrossRef]

45. Liu, Y.; Gayle, A.A.; Wilder-Smith, A.; Rocklöv, J. The reproductive number of COVID-19 is higher compared to SARS coronavirus. J. Travel Med. 2020, 27, 21. [CrossRef] [PubMed]

46. Kucharski, A.; Althaus, C. The role of superspreading in Middle East respiratory syndrome coronavirus (MERS-CoV) transmission. Euro Surveill. 2015, 20, 21167. [CrossRef] [PubMed]

47. Chen, H.; Guo, J.; Wang, C.; Luo, F.; Yu, X.; Zhang, W.; Li, J.; Zhao, D.; Xu, D.; Gong, Q.; et al. Clinical characteristics and intrauterine vertical transmission potential of COVID-19 infection in nine pregnant women: A retrospective review of medical records. Lancet 2020, 395, 809-815. [CrossRef]

48. McBride, R.; van Zyl, M.; Fielding, B.C. The Coronavirus Nucleocapsid Is a Multifunctional Protein. Viruses 2014, 6, 2991-3018. [CrossRef] [PubMed]

49. Coutard, B.; Valle, C.; de Lamballerie, X.; Canard, B.; Seidah, N.G.; Decroly, E. The spike glycoprotein of the new coronavirus 2019-nCoV contains a furin-like cleavage site absent in CoV of 350 the same clade. Antivir. Res. 2020, 176, 104742. [CrossRef]

50. Klausegger, A.; Strobl, B.; Regl, G.; Kaser, A.; Luytjes, W.; Vlasak, R. Identification of a Coronavirus Hemagglutinin-Esterase with a Substrate Specificity Different from Those of Influenza C Virus and Bovine Coronavirus. J. Virol. 1999, 73, 3737-3743. [CrossRef]

51. Bárcena, M.; Oostergetel, G.T.; Bartelink, W.; Faas, F.G.; Verkleij, A.; Rottier, P.J.; Koster, A.J.; Bosch, B.J. Cryo-electron tomography of mouse hepatitis virus: Insight to the structure of the coronavirion. Proc. Natl. Acad. Sci. USA 2009, 106, 582-587. [CrossRef]

52. Mortola, E.; Roy, P. Efficient assembly and release of SARS coronavirus-like particles by a heterologous expression system. FEBS Lett. 2004, 576, 174-178. [CrossRef] [PubMed]

53. Beniac, D.R.; Andonov, A.; Grudeski, E.; Booth, T.F. Architecture of the SARS coronavirus prefusion spike. Nat. Struct. Mol. Biol. 2006, 13, 751-752. [CrossRef] [PubMed]

54. Delmas, B.; Laude, H. Assembly of coronavirus spike protein into trimers and its role in epitope expression. J. Virol. 1990, 64, 5367-5375. [CrossRef] [PubMed]

55. Nal, B. Differential maturation and subcellular localization of severe acute respiratory syndrome coronavirus surface proteins $\mathrm{S}$, M and E. J. Gen. Virol. 2005, 86, 1423-1434. [CrossRef] [PubMed]

56. Neuman, B.W.; Kiss, G.; Kunding, A.H.; Bhella, D.; Baksh, M.F.; Connelly, S.; Droese, B.; Klaus, J.P.; Makino, S.; Sawicki, S.G.; et al. A structural analysis of M protein in coronavirus assembly and morphology. J. Struct. Biol. 2011, 174, 11-22. [CrossRef]

57. De Diego, M.L.; Âlvarez, E.; Almazán, F.; Rejas, M.T.; Lamirande, E.; Roberts, A.; Shieh, W.-J.; Zaki, S.R.; Subbarao, K.; Enjuanes, L. A Severe Acute Respiratory Syndrome Coronavirus That Lacks the E Gene Is Attenuated In Vitro and In Vivo. J. Virol. 2006, 81, 1701-1713. [CrossRef] [PubMed]

58. Nieto-Torres, J.L.; de Diego, M.L.; Verdiá-Báguena, C.; Jimenez-Guardeño, J.M.; Regla-Nava, J.A.; Fernandez-Delgado, R.; Castaño-Rodriguez, C.; Alcaraz, A.; Torres, J.; Aguilella, V.M. Severe acute respiratory syndrome coronavirus envelope protein ion channel activity promotes virus fitness and pathogenesis. PLoS Pathog. 2014, 10, e1004077. [CrossRef] [PubMed]

59. Fehr, A.R.; Perlman, S. Coronaviruses: An overview of their replication and pathogenesis. Methods Mol. Biol. $2015,1282,1-23$.

60. Chang, C.-K.; Sue, S.-C.; Yu, T.-H.; Hsieh, C.-M.; Tsai, C.-K.; Chiang, Y.-C.; Lee, S.-J.; Hsiao, H.-H.; Wu, W.-J.; Chang, W.-L.; et al. Modular organization of SARS coronavirus nucleocapsid protein. J. Biomed. Sci. 2005, 13, 59-72. [CrossRef]

61. Hurst, K.R.; Koetzner, C.A.; Masters, P.S. Identification of In Vivo-Interacting Domains of the Murine Coronavirus Nucleocapsid Protein. J. Virol. 2009, 83, 7221-7234. [CrossRef]

62. Cui, L.; Wang, H.; Ji, Y.; Yang, J.; Xu, S.; Huang, X.; Wang, Z.; Qin, L.; Tien, P.; Zhou, X.; et al. The Nucleocapsid Protein of Coronaviruses Acts as a Viral Suppressor of RNA Silencing in Mammalian Cells. J. Virol. 2015, 89, 9029-9043. [CrossRef] 
63. Tan, Y.J.; Goh, P.Y.; Fielding, B.C.; Shen, S.; Chou, C.F.; Fu, J.L.; Leong, H.N.; Leo, Y.S.; Ooi, E.E.; Ling, A.E.; et al. Profiles of Antibody Responses against Severe Acute Respiratory Syndrome Coronavirus Recombinant Proteins and Their Potential Use as Diagnostic Markers. Clin. Diagn. Lab. Immunol. 2004, 11, 362-371. [CrossRef] [PubMed]

64. Deng, X.; Stjohn, S.E.; Osswald, H.L.; O'Brien, A.; Banach, B.S.; Sleeman, K.; Ghosh, A.K.; Mesecar, A.D.; Baker, S.C. Coronaviruses Resistant to a 3C-Like Protease Inhibitor Are Attenuated for Replication and Pathogenesis, Revealing a Low Genetic Barrier but High Fitness Cost of Resistance. J. Virol. 2014, 88, 1186-11898. [CrossRef] [PubMed]

65. Götte, B.; Liu, L.; McInerney, G.M. The enigmatic alphavirus non-structural protein 3 (nsP3) revealing its secretsat last. Viruses 2018, 10, 105. [CrossRef] [PubMed]

66. Kirchdoerfer, R.N.; Ward, A.B. Structure of the SARS-CoV nsp12 polymerase bound to nsp7 and nsp8 co365 factors. Nat. Commun 2019, 10, 2342. [CrossRef] [PubMed]

67. Huang, C.; Lokugamage, K.G.; Rozovics, J.M.; Narayanan, K.; Semler, B.L.; Makino, S. SARS coronavirus nsp1 protein induces template-dependent endonucleolytic cleavage of mRNAs: Viral mRNAs are resistant to nsp1-induced RNA cleavage. PLoS Pathog. 2011, 7, e1002433. [CrossRef]

68. Tanaka, T.; Kamitani, W.; de Diego, M.L.; Enjuanes, L.; Matsuura, Y. Severe Acute Respiratory Syndrome Coronavirus nsp1 Facilitates Efficient Propagation in Cells through a Specific Translational Shutoff of Host mRNA. J. Virol. 2012, 86, 11128-11137. [CrossRef]

69. Graham, R.L.; Sims, A.C.; Brockway, S.M.; Baric, R.S.; Denison, M.R. The nsp2 Replicase Proteins of Murine Hepatitis Virus and Severe Acute Respiratory Syndrome Coronavirus Are Dispensable for Viral Replication. J. Virol. 2005, 79, 13399-13411. [CrossRef]

70. Gadlage, M.J.; Graham, R.L.; Denison, M.R. Murine Coronaviruses Encoding nsp2 at Different Genomic Loci Have Altered Replication, Protein Expression, and Localization. J. Virol. 2008, 82, 11964-11969. [CrossRef]

71. Lei, J.; Kusov, Y.; Hilgenfeld, R. Nsp3 of coronaviruses: Structures and functions of a large multi-domain protein. Antivir. Res. 2018, 149, 58-74. [CrossRef]

72. Serrano, P.; Johnson, M.A.; Chatterjee, A.; Neuman, B.W.; Joseph, J.S.; Buchmeier, M.J.; Kuhn, P.; Wüthrich, K. Nuclear Magnetic Resonance Structure of the Nucleic Acid-Binding Domain of Severe Acute Respiratory Syndrome Coronavirus Nonstructural Protein 3. J. Virol. 2009, 83, 12998-13008. [CrossRef]

73. Beachboard, D.C.; Anderson-Daniels, J.M.; Denison, M.R. Mutations across Murine Hepatitis Virus nsp4 Alter Virus Fitness and Membrane Modifications. J. Virol. 2014, 89, 2080-2089. [CrossRef]

74. Gadlage, M.J.; Sparks, J.S.; Beachboard, D.C.; Cox, R.G.; Doyle, J.D.; Stobart, C.C.; Denison, M.R. Murine Hepatitis Virus Nonstructural Protein 4 Regulates Virus-Induced Membrane Modifications and Replication Complex Function. J. Virol. 2009, 84, 280-290. [CrossRef]

75. Stobart, C.C.; Sexton, N.R.; Munjal, H.; Lu, X.; Molland, K.L.; Tomar, S.; Mesecar, A.D.; Denison, M.R. Chimeric Exchange of Coronavirus nsp5 Proteases (3CLpro) Identifies Common and Divergent Regulatory Determinants of Protease Activity. J. Virol. 2013, 87, 12611-12618. [CrossRef]

76. Zhu, X.; Fang, L.; Wang, D.; Yang, Y.; Chen, J.; Ye, X.; Foda, M.F.; Xiao, S. Porcine delta coronavirus nsp5 inhibits interferon-beta production through the cleavage of NEMO. Virology 2017, 502, 33-38. [CrossRef] [PubMed]

77. Zhu, X.; Wang, D.; Zhou, J.; Pan, T.; Chen, J.; Yang, Y.; Lv, M.; Ye, X.; Peng, G.; Fang, L.; et al. Porcine Deltacoronavirus nsp5 Antagonizes Type I Interferon Signaling by Cleaving STAT2. J. Virol. 2017, 91, e00003-17. [CrossRef] [PubMed]

78. Angelini, M.M.; Akhlaghpour, M.; Neuman, B.W.; Buchmeier, M.J. Severe Acute Respiratory Syndrome Coronavirus Nonstructural Proteins 3, 4, and 6 Induce Double-Membrane Vesicles. mBio 2013, 4, 00524-13. [CrossRef]

79. Cottam, E.M.; Whelband, M.C.; Wileman, T. Coronavirus NSP6 restricts autophagosome expansion. Autophagy 2014, 10, $1426-1441$. [CrossRef]

80. Zhai, Y.; Sun, F.; Li, X.; Pang, H.; Xu, X.; Bartlam, M.; Rao, Z. Insights into SARS-CoV transcription and replication from the structure of the nsp7-nsp8 hexadecamer. Nat. Struct. Mol. Biol. 2005, 12, 980-986. [CrossRef] [PubMed]

81. Velthuis, A.J.T.; Worm, S.H.E.V.D.; Snijder, E.J. The SARS-coronavirus nsp7+nsp8 complex is a unique multimeric RNA polymerase capable of both de novo initiation and primer extension. Nucleic Acids Res. 2011, 40, 1737-1747. [CrossRef]

82. Egloff, M.-P.; Ferron, F.; Campanacci, V.; Longhi, S.; Rancurel, C.; Dutartre, H.; Snijder, E.J.; Gorbalenya, A.E.; Cambillau, C.; Canard, B. The severe acute respiratory syndrome-coronavirus replicative protein nsp9 is a single-stranded RNA-binding subunit unique in the RNA virus world. Proc. Natl. Acad. Sci. USA 2004, 101, 3792-3796. [CrossRef]

83. Zeng, Z.; Deng, F.; Shi, K.; Ye, G.; Wang, G.; Fang, L.; Xiao, S.; Fu, Z.; Peng, G. Dimerization of Coronavirus nsp9 with Diverse Modes Enhances Its Nucleic Acid Binding Affinity. J. Virol. 2018, 92, e00692-18. [CrossRef]

84. Bouvet, M.; Lugari, A.; Posthuma, C.C.; Zevenhoven, J.C.; Bernard, S.; Betzi, S.; Imbert, I.; Canard, B.; Guillemot, J.-C.; Lécine, P.; et al. Coronavirus Nsp10, a Critical Co-factor for Activation of Multiple Replicative Enzymes. J. Biol. Chem. 2014, 289, 25783-25796. [CrossRef] [PubMed]

85. Chen, Y.; Su, C.; Ke, M.; Jin, X.; Xu, L.; Zhang, Z.; Wu, A.; Sun, Y.; Yang, Z.; Tien, P.; et al. Biochemical and Structural Insights into the Mechanisms of SARS Coronavirus RNA Ribose 2'-O-Methylation by nsp16/nsp10 Protein Complex. PLoS Pathog. 2011, 7, e1002294. [CrossRef] [PubMed]

86. Decroly, E.; Debarnot, C.; Ferron, F.; Bouvet, M.; Coutard, B.; Imbert, I.; Gluais, L.; Papageorgiou, N.; Sharff, A.; Bricogne, G.; et al. Crystal Structure and Functional Analysis of the SARS-Coronavirus RNA Cap 2'-O-Methyltransferase nsp10/nsp16 Complex. PLoS Pathog. 2011, 7, e1002059. [CrossRef] [PubMed] 
87. Ma, Y.; Wu, L.; Shaw, N.; Gao, Y.; Wang, J.; Sun, Y.; Lou, Z.; Yan, L.; Zhang, R.; Rao, Z. Structural basis and functional analysis of the SARS coronavirus nsp14-nsp10 complex. Proc. Natl. Acad. Sci. USA 2015, 112, 9436-9441. [CrossRef] [PubMed]

88. Fang, S.G.; Shen, H.; Wang, J.; Tay, F.P.L.; Liu, D.X. Proteolytic processing of polyproteins 1a and 1ab between non-structural proteins 10 and 11/ 12 of coronavirus infectious bronchitis virus is dispensable for viral replication in cultured cells. Virology, $2008 ; 379,175-180$.

89. Ahn, D.-G.; Choi, J.-K.; Taylor, D.R.; Oh, J.-W. Biochemical characterization of a recombinant SARS coronavirus nsp12 RNAdependent RNA polymerase capable of copying viral RNA templates. Arch. Virol. 2012, 157, 2095-2104. [CrossRef] [PubMed]

90. Velthuis, A.J.W.T.; Arnold, J.J.; Cameron, C.E.; Worm, S.H.E.V.D.; Snijder, E.J. The RNA polymerase activity of SARS-coronavirus nsp12 is primer dependent. Nucleic Acids Res. 2009, 38, 203-214. [CrossRef]

91. Adedeji, A.O.; Lazarus, H. Biochemical Characterization of Middle East Respiratory Syndrome Coronavirus Helicase. $m S p h e r e$ 2016, 1, e00235-16. [CrossRef] [PubMed]

92. Hao, W.; Wojdyla, J.A.; Zhao, R.; Han, R.; Das, R.; Zlatev, I.; Manoharan, M.; Wang, M.; Cui, S. Crystal structure of Middle East respiratory syndrome coronavirus helicase. PLoS Pathog. 2017, 13, e1006474. [CrossRef]

93. Jia, Z.; Yan, L.; Ren, Z.; Wu, L.; Wang, J.; Guo, J.; Zheng, L.; Ming, Z.; Zhang, L.; Lou, Z.; et al. Delicate structural coordination of the Severe Acute Respiratory Syndrome coronavirus Nsp13 upon ATP hydrolysis. Nucleic Acids Res. 2019, 47, 6538-6550. [CrossRef]

94. Bouvet, M.; Imbert, I.; Subissi, L.; Gluais, L.; Canard, B.; Decroly, E. RNA 3'-end mismatch excision by the severe acute respiratory syndrome coronavirus nonstructural protein nsp10/nsp14 exoribonuclease complex. Proc. Natl. Acad. Sci. USA 2012, 109, 9372-9377. [CrossRef] [PubMed]

95. Chen, Y.; Cai, H.; Pan, J.; Xiang, N.; Tien, P.; Ahola, T.; Guo, D. Functional screen reveals SARS coronavirus nonstructural protein nsp14 as a novel cap N7 methyltransferase. Proc. Natl. Acad. Sci. USA 2009, 106, 3484-3489. [CrossRef]

96. Minskaia, E.; Hertzig, T.; Gorbalenya, A.E.; Campanacci, V.; Cambillau, C.; Canard, B.; Ziebuhr, J. Discovery of an RNA virus $3^{\prime} \rightarrow 5^{\prime}$ exoribonuclease that is critically involved in coronavirus RNA synthesis. Proc. Natl. Acad. Sci. USA 2006, 103, 5108-5113. [CrossRef]

97. Eckerle, L.D.; Becker, M.M.; Halpin, R.A.; Li, K.; Venter, E.; Lu, X.; Scherbakova, S.; Graham, R.L.; Baric, R.S.; Stockwell, T.B.; et al. Infidelity of SARS-CoV Nsp14-Exonuclease Mutant Virus Replication Is Revealed by Complete Genome Sequencing. PLoS Pathog. 2010, 6, e1000896. [CrossRef] [PubMed]

98. Bhardwaj, K.; Sun, J.; Holzenburg, A.; Guarino, L.A.; Kao, C.C. RNA Recognition and Cleavage by the SARS Coronavirus Endoribonuclease. J. Mol. Biol. 2006, 361, 243-256. [CrossRef] [PubMed]

99. Deng, X.; Hackbart, M.; Mettelman, R.C.; O’Brien, A.; Mielech, A.M.; Yi, G.; Kao, C.C.; Baker, S.C. Coronavirus nonstructural protein 15 mediates evasion of dsRNA sensors and limits apoptosis in macrophages. Proc. Natl. Acad. Sci. USA 2017, 114, E4251-E4260. [CrossRef]

100. Zhang, L.; Li, L.; Yan, L.; Ming, Z.; Jia, Z.; Lou, Z.; Rao, Z. Structural and Biochemical Characterization of Endoribonuclease Nsp15 Encoded by Middle East Respiratory Syndrome Coronavirus. J. Virol. 2018, 92, e00893-18. [CrossRef] [PubMed]

101. Shi, P.; Su, Y.; Li, R.; Liang, Z.; Dong, S.; Huang, J. PEDV nsp16 negatively regulates innate immunity to promote viral proliferation. Virus Res. 2019, 265, 57-66.

102. Van Boheemen, S.; de Graaf, M.; Lauber, C.; Bestebroer, T.; Raj, V.; Zaki, A.; Osterhaus, A.; Haagmans, B.; Gorbalenya, A.; Snijder, E.; et al. Genomic Characterization of a Newly Discovered Coronavirus Associated with Acute Respiratory Distress Syndrome in Humans. mBio 2012, 3, 00473-12. [CrossRef]

103. Raj, V.S.; Mou, H.; Smits, S.L.; Dekkers, D.H.W.; Müller, M.A.; Dijkman, R.; Muth, D.; Demmers, J.A.A.; Zaki, A.; Fouchier, R.A.M.; et al. Dipeptidyl peptidase 4 is a functional receptor for the emerging human coronavirus-EMC. Nature 2013, 495, 251-254. [CrossRef]

104. Perlman, S.; Netland, J. Coronaviruses post-SARS: Update on replication and pathogenesis. Nat. Rev. Genet. 2009, 7, 439-450. [CrossRef] [PubMed]

105. Wang, N.; Shi, X.; Jiang, L.; Zhang, S.; Wang, D.; Tong, P.; Guo, D.; Fu, L.; Cui, Y.; Liu, X.; et al. Structure of MERS-CoV spike receptor-binding domain complexed with human receptor DPP4. Cell Res. 2013, 23, 986. [CrossRef] [PubMed]

106. Bertram, S.; Glowacka, I.; Müller, M.A.; Lavender, H.; Gnirss, K.; Nehlmeier, I.; Niemeyer, D.; He, Y.; Simmons, G.; Drosten, C.; et al. Cleavage and Activation of the Severe Acute Respiratory Syndrome Coronavirus Spike Protein by Human Airway Trypsin-Like Protease. J. Virol. 2011, 85, 13363-13372. [CrossRef] [PubMed]

107. Glowacka, I.; Bertram, S.; Müller, M.A.; Allen, P.D.; Soilleux, E.J.; Pfefferle, S.; Steffen, I.; Tsegaye, T.S.; He, Y.; Gnirss, K.; et al. Evidence that TMPRSS2 Activates the Severe Acute Respiratory Syndrome Coronavirus Spike Protein for Membrane Fusion and Reduces Viral Control by the Humoral Immune Response. J. Virol. 2011, 85, 4122-4134. [CrossRef]

108. Wu, F.; Zhao, S.; Yu, B.; Chen, Y.M.; Wang, W.; Song, Z.G.; Hu, Y.; Tao, Z.W.; Tian, J.H.; Pei, Y.Y.; et al. A new coronavirus associated with human respiratory disease in China. Nature 2020, 579, 265-269. [CrossRef] [PubMed]

109. Xu, X.; Chen, P.; Wang, J.; Feng, J.; Zhou, H.; Li, X.; Zhong, W.; Hao, P. Evolution of the novel coronavirus from the ongoing Wuhan outbreak and modeling of its spike protein for risk of human transmission. Sci. China Life Sci. 2020, 63, 457-460. [CrossRef] [PubMed]

110. Wan, Y.; Shang, J.; Graham, R.; Baric, R.S.; Li, F. Receptor recognition by novel coro-navirus from Wuhan: An analysis based on decade-long structural studies of SARS. J Virol. 2020. [CrossRef] 
111. Wang, D.; Hu, B.; Hu, C.; Zhu, F.; Liu, X.; Zhang, J.; Wang, B.; Xiang, H.; Cheng, Z.; Xiong, Y.; et al. Clinical Characteristics of 138 Hospitalized Patients With 2019 Novel Coronavirus-Infected Pneumonia in Wuhan, China. JAMA 2020, 323, 1061-1069. [CrossRef]

112. Chang, D.; Lin, M.; Wei, L.; Xie, L.; Zhu, G.; Cruz, C.S.D.; Sharma, L. Epidemiologic and Clinical Characteristics of Novel Coronavirus Infections Involving 13 Patients Outside Wuhan, China. JAMA 2020, 323, 1092. [CrossRef]

113. Chen, N.; Zhou, M.; Dong, X.; Qu, J.; Gong, F.; Han, Y.; Qiu, Y.; Wang, J.; Liu, Y.; Wei, Y. Epidemiological and clinical characteristics of 99 cases of 2019 novel coronavirus pneumonia in Wuhan, China: A descriptive study. Lancet 2020, 395, 507-513. [CrossRef]

114. Liu, W.; Zhang, Q.; Chen, J.; Xiang, R.; Song, H.; Shu, S.; Chen, L.; Liang, L.; Zhou, J.; You, L.; et al. Detection of Covid-19 in Children in Early January 2020 in Wuhan, China. N. Engl. J. Med. 2020, 382, 1370-1371. [CrossRef]

115. Shen, K.L.; Yang, Y.H. Diagnosis and treatment of 2019 novel coronavirus infectionin children: A pressing issue. World J. Pediatr. 2020, 16, 219-221.

116. Guan, W.J.; Ni, Z.Y.; Hu, Y.; Liang, W.H.; Ou, C.Q.; He, J.X.; Liu, L.; Shan, H.; Lei, C.L.; Hui, D.S. Clinical characteristics of 2019 novel coronavirus infection in China. medRxiv 2020, 1-10. [CrossRef]

117. Zhang, J.-J.; Dong, X.; Cao, Y.-Y.; Yuan, Y.-D.; Yang, Y.-B.; Yan, Y.-Q.; Akdis, C.A.; Gao, Y.-D. Clinical characteristics of 140 patients infected with SARS-CoV-2 in Wuhan, China. Allergy 2020, 75, 1730-1741. [CrossRef] [PubMed]

118. Zumla, A.; Hui, D.S.; Perlman, S. Middle East respiratory syndrome. Lancet 2015, 386, 995-1007. [CrossRef]

119. Al-Omari, A.; Rabaan, A.A.; Salih, S.; Al-Tawfiq, J.A.; Memish, Z.A. MERS coronavirus outbreak: Implications for emerging viral infections. Diagn. Microbiol. Infect. Dis. 2019, 93, 265-285. [CrossRef] [PubMed]

120. Yeung, M.-L.; Yao, Y.; Jia, L.; Chan, J.F.W.; Chan, K.-H.; Cheung, K.-F.; Chen, H.; Poon, V.K.M.; Tsang, A.K.L.; To, K.K.; et al. MERS coronavirus induces apoptosis in kidney and lung by upregulating Smad7 and FGF2. Nat. Microbiol. 2016, 1, 16004. [CrossRef]

121. Li, W.; Moore, M.J.; Vasilieva, N.; Sui, J.; Wong, S.K.; Berne, M.A.; Somasundaran, M.; Sullivan, J.L.; Luzuriaga, K.; Greenough, T.C.; et al. Angiotensin-converting enzyme 2 is a functional receptor for the SARS coronavirus. Nature 2003, 426, 450-454. [CrossRef]

122. Chen, Y.; Guo, Y.; Pan, Y.; Zhao, Z.J. Structure analysis of the receptor binding of 2019-nCoV. Biochem. Biophys. Res. Commun. 2020, 525, 135-140. [CrossRef]

123. Walls, A.C.; Park, Y.J.; Tortorici, M.A.; Wall, A.; McGuire, A.T.; Veesler, D. Structure, function, and antigenicity of the SARS-CoV-2 spike glycoprotein. Cell 2020, 180, 281-292. [CrossRef]

124. Letko, M.; Marzi, A.; Munster, V. Functional assessment of cell entry and receptor usage for SARS-CoV-2 and other lineage B betacoronaviruses. Nat. Microbiol. 2020, 5, 562-569. [CrossRef]

125. Zou, X.; Chen, K.; Zou, J.; Han, P.; Hao, J.; Han, Z. Single-cell RNA-seq data analysis on the receptor ACE2 expression reveals the potential risk of different human organs vulnerable to 2019-nCoV infection. Front. Med. 2020, 14, 185-192. [CrossRef] [PubMed]

126. Chan-Yeung, M.; Xu, R.-H. SARS: Epidemiology. Respirology 2003, 8, S9-S14. [CrossRef] [PubMed]

127. Li, B.; Yang, J.; Zhao, F.; Zhi, L.; Wang, X.; Liu, L.; Bi, Z.; Zhao, Y. Prevalence and impact of cardiovascular metabolic diseases on COVID-19 in China. Clin. Res. Cardiol. 2020, 109, 531-538. [CrossRef]

128. Saavedra, J.M. Angiotensin receptor blockers and COVID-19. Pharmacol. Res. 2020, 156, 104832. [CrossRef] [PubMed]

129. Belouzard, S.; Chu, V.C.; Whittaker, G.R. Activation of the SARS coronavirus spike protein via sequential proteolytic cleavage at two distinct sites. Proc. Natl. Acad. Sci. USA 2009, 106, 5871-5876. [CrossRef] [PubMed]

130. Millet, J.K.; Whittaker, G.R. Host cell entry of Middle East respiratory syndrome coronavirus after two-step, furin-mediated activation of the spike protein. Proc. Natl. Acad. Sci. USA 2014, 111, 15214-15219. [CrossRef] [PubMed]

131. Ou, X.; Liu, Y.; Lei, X.; Li, P.; Mi, D.; Ren, L.; Guo, L.; Guo, R.; Chen, T.; Hu, J. Characterization of spike glycoprotein of SARS-CoV-2 on virus entry and its immune cross-reactivity with SARS-CoV. Nat. Commun. 2020, 11, 1620. [CrossRef]

132. Belouzard, S.; Millet, J.K.; Licitra, B.N.; Whittaker, G.R. Mechanisms of Coronavirus Cell Entry Mediated by the Viral Spike Protein. Viruses 2012, 4, 1011-1033. [CrossRef]

133. Hoffmann, M.; Kleine-Weber, H.; Schroeder, S.; Kruger, N.; Herrler, T.; Erichsen, S.; Schiergens, T.S.; Herrler, G.; Wu, N.-H.; Nitsche, A. SARS-CoV-2 cell entry depends on ACE2 and TMPRSS2 and is blocked by a clinically proven protease inhibitor. Cell 2020, 181, 1-10. [CrossRef] [PubMed]

134. Lu, R.; Zhao, X.; Li, J.; Niu, P.; Yang, B.; Wu, H.; Wang, W.; Song, H.; Huang, B.; Zhu, N.; et al. Genomic characterisation and epidemiology of 2019 novel coronavirus: Implications for virus origins and receptor binding. Lancet 2020, 395, 565-574. [CrossRef]

135. Totura, A.L.; Baric, R.S. SARS coronavirus pathogenesis: Host innate immune responses and viral antagonism of interferon. Curr. Opin. Virol. 2012, 2, 264-275. [CrossRef]

136. Hamming, I.; Timens, W.; Bulthuis, M.L.; Lely, A.T.; Navis, G.; van Goor, H. Tissue distribution of ACE2 protein, the functional receptor for SARS coronavirus. A firststep in understanding SARS pathogenesis. J. Pathol. 2004, 203, 631-637. [CrossRef] [PubMed]

137. Wong, C.K.; Lam, C.W.K.; Wu, A.K.L.; Ip, W.K.; Lee, N.L.S.; Chan, I.H.S.; Lit, L.C.W.; Hui, D.S.C.; Chan, M.H.M.; Chung, S.S.C. Plasma inflammatory cytokines and chemokines in severe acute respiratory syndrome. Clin. ExpImmunol. 2004, 136, 95-103. [CrossRef]

138. Smits, S.L.; de Lang, A.; van den Brand, J.M.; Leijten, L.M.; van Ijcken, W.F.; Eijkemans, M.J.; van Amerongen, G.; Kuiken, T.; Andeweg, A.C.; Osterhaus, A.D. Exacerbated innate host response to SARS-CoV in aged non-human primates. PLoS Pathog. 2010, 6, e1000756. 
139. Jin, Y.H.; Cai, L.; Cheng, Z.S.; Cheng, H.; Deng, T.; Fan, Y.P.; Fang, C.; Huang, D.; Huang, L.Q.; Huang, Q. A rapid advice guideline forthe diagnosis and treatment of 2019 novel coronavirus (2019-nCoV) infected pneumonia (standard version). Mil. Med. Res. 2020, 7, 4. [PubMed]

140. Lei, J.; Li, J.; Li, X.; Qi, X. CT Imaging of the 2019 Novel Coronavirus (2019-nCoV) Pneumonia. Radiology 2020, 295, 18. [CrossRef]

141. Zhu, N.; Zhang, D.; Wang, W.; Li, X.; Yang, B.; Song, J.; Zhao, X.; Huang, B.; Shi, W.; Lu, R.; et al. A Novel Coronavirus from Patients with Pneumonia in China, 2019. N. Engl. J. Med. 2020, 382, 727-733. [CrossRef] [PubMed]

142. Chung, M.; Bernheim, A.; Mei, X.; Zhang, N.; Huang, M.; Zeng, X.; Cui, J.; Xu, W.; Yang, Y.; Fayad, Z.A. CT imaging features of 2019 novel coronavirus (2019-nCoV). Radiology 2020, 295, 200-230. [CrossRef] [PubMed]

143. Habibzadeh, P.; Stoneman, E.K. The novel coronavirus: A bird's eye view. Int. J. Occup. Environ. Med. 2020, 11, 65-71. [CrossRef]

144. WHO (World Health Organization). Global Surveillance for Human Infection with Novel Coronavirus (2019-nCoV); WHO: New York, NY, USA, 2020.

145. Russell, C.C.; Millar, J.K.; Baillie, J.E. Clinical evidence does not support corticosteroid treatment for 2019-nCoV lung injury. Lancet 2020, 395, 473-475.

146. Wang, M.; Cao, R.; Zhang, L.; Yang, X.; Liu, J.; Xu, M.; Shi, Z.; Hu, Z.; Zhong, W.; Xiao, G. Remdesivir and chloroquine effectively inhibit the recently emerged novel coronavirus (2019-nCoV) in vitro. Cell Res. 2020, 30, 269-271. [CrossRef] [PubMed]

147. Ng, C.S.; Kasumba, D.M.; Fujita, T.; Luo, H. Spatio-temporal characterization of the antiviral activity of the XRN1-DCP1/2 aggregation against cytoplasmic RNA viruses to prevent cell death. Cell Death Differ 2020, 8, 1-20. Correction in 2020, 27, 2363-2382. [CrossRef] [PubMed]

148. Wang, B.X.; Fish, E.N. Global virus outbreaks: Interferons as 1st responders. Semin. Immunol. 2019, 43, 101300. [CrossRef]

149. Agostini, M.L.; Andres, E.L.; Sims, A.C.; Graham, R.L.; Sheahan, T.P.; Lu, X.; Smith, E.C.; Case, J.B.; Feng, J.Y.; Jordan, R.; et al. Coronavirus Susceptibility to the Antiviral Remdesivir (GS-5734) Is Mediated by the Viral Polymerase and the Proofreading Exoribonuclease. mBio 2018, 9, e00221-18. [CrossRef] [PubMed]

150. Paules, C.I.; Marston, H.D.; Fauci, A.S. Coronavirus infections-More than just the common cold. JAMA 2020, 323, 707-708. [CrossRef]

151. Holshue, M.L.; de Bolt, C.; Lindquist, S.; Lofy, K.H.; Wiesman, J.; Bruce, H.; Spitters, C.; Ericson, K.; Wilkerson, S.; Tural, A.; et al. First Case of 2019 Novel Coronavirus in the United States. N. Engl. J. Med. 2020, 382, 929-936. [CrossRef]

152. Sheahan, T.P.; Sims, A.C.; Leist, S.R.; Schäfer, A.; Won, J.; Brown, A.J.; Montgomery, S.A.; Hogg, A.; Babusis, D.; Clarke, M.O.; et al. Comparative therapeutic efficacy of remdesivir and combination lopinavir, ritonavir, and interferon beta against MERS-CoV. Nat. Commun. 2020, 11, 222. [CrossRef] [PubMed]

153. Richardson, P.; Griffin, I.; Tucker, C.; Smith, D.; Oechsle, O.; Phelan, A.; Rawling, M.; Savory, E.; Stebbing, J. Baricitinib as potential treatment for 2019-nCoV acute respiratory disease. Lancet 2020, 395, e30-e31. [CrossRef]

154. Liu, X.; Wang, X.-J. Potential inhibitors against 2019-nCoV coronavirus M protease from clinically approved medicines. J. Genet. Genom. 2020, 47, 119-121. [CrossRef] [PubMed]

155. Lu, H. Drug treatment options for the 2019-new coronavirus (2019-nCoV). Biosci. Trends 2020, 14, 69-71. [CrossRef]

156. Gordon, C.J.; Tchesnokov, E.P.; Feng, J.Y.; Porter, D.P.; Götte, M. The antiviral compound remdesivir potently inhibits RNAdependent RNA polymerase from Middle East respiratory syndrome coronavirus. J. Biol. Chem. 2020, 295, 4773-4779. [CrossRef]

157. Chen, S.; Chan, K.; Jiang, Y.; Kao, R.; Lu, H.; Fan, K.; Cheng, V.; Tsui, W.; Hung, I.; Lee, T. In vitro susceptibility of 10 clinical isolates of SARS coronavirus to selected antiviral compounds. J. Clin. Virol. 2004, 31, 69-75. [CrossRef]

158. Yao, T.; Qian, J.; Zhu, W.; Wang, Y.; Wang, G. A systematic review of lopinavir therapy for SARS coronavirus and MERS coronavirus-A possible reference for coronavirus disease-19 treatment option. J. Med Virol. 2020, 92, 556-563. [CrossRef]

159. Riva, A.; Conti, F.; Bernacchia, D.; Pezzati, L.; Sollima, S.; Merli, S.; Siano, M.; Lupo, A.; Rusconi, S.; Cattaneo, D. Darunavir does not prevent SARS-CoV-2 infection in HIV patients. Pharmacol. Res. 2020, 157, 104826. [CrossRef] [PubMed]

160. Furuta, Y.; Gowen, B.B.; Takahashi, K.; Shiraki, K.; Smee, D.F.; Barnard, D.L. Favipiravir (T-705), a novel viral RNA polymerase inhibitor. Antivir. Res. 2013, 100, 446-454. [CrossRef] [PubMed]

161. Stockman, L.J.; Bellamy, R.; Garner, P. SARS: Systematic Review of Treatment Effects. PLoS Med. 2006, 3, e343. [CrossRef]

162. Kadam, R.U.; Wilson, I.A. Structural basis of influenza virus fusion inhibition by the antiviral drug Arbidol. Proc. Natl. Acad. Sci. USA 2017, 114, 206-214. [CrossRef]

163. Khamitov, R.A.; Loginova, S.; Shchukina, V.N.; Borisevich, S.V.; Maksimov, V.A.; Shuster, A.M. Antiviral activity of arbidoland its derivatives against the pathogen of severe acute respiratory syndromein the cell cultures. Vopr. Virusol. 2008, 53, 9.

164. Al-Bari, M.A.A. Targeting endosomal acidification by chloroquine analogs as a promising strategy for the treatment of emerging viral diseases. Pharmacol. Res. Perspect. 2017, 5, e00293. [CrossRef] [PubMed]

165. Yao, X.; Ye, F.; Zhang, M.; Cui, C.; Huang, B.; Niu, P.; Liu, X.; Zhao, L.; Dong, E.; Song, C.; et al. In Vitro Antiviral Activity and Projection of Optimized Dosing Design of Hydroxychloroquine for the Treatment of Severe Acute Respiratory Syndrome Coronavirus 2 (SARS-CoV-2). Clin. Infect. Dis. 2020, 71, 732-739. [CrossRef]

166. Caly, L.; Druce, J.D.; Catton, M.G.; Jans, D.A.; Wagstaff, K.M. The FDA-Approved Drug Ivermectin inhibits the replication ofSARS-CoV-2 in vitro. J Antivir. 2020, 178, 1047-1087.

167. Rossignol, J.-F. Nitazoxanide, a new drug candidate for the treatment of Middle East respiratory syndrome coronavirus. J. Infect. Public Heal. 2016, 9, 227-230. [CrossRef] [PubMed] 
168. Zhao, Z.; Zhang, F.; Xu, M.; Huang, K.; Zhong, W.; Cai, W.; Yin, Z.; Huang, S.; Deng, Z.; Wei, M.; et al. Description and clinical treatment of an early outbreak of severe acute respiratory syndrome (SARS) in Guangzhou, PR China. J. Med. Microbiol. 2003, 52, 715-720. [CrossRef] [PubMed]

169. Gautret, P.; Lagier, J.C.; Parola, P.; Meddeb, L.; Mailhe, M.; Doudier, B.; Courjon, J.; Giordanengo, V.; Vieira, V.E.; Dupont, H.T.; et al. Hydroxychloroquine and Azithryomycin as a treatment of COVID-results of an openlabel non-randomized clinical trial. Int. J. Antimicrob. Agents. 2020, 20, 105949. [CrossRef]

170. Pan, L.; Mu, M.; Yang, P.; Sun, Y.; Wang, R.; Yan, J.; Li, P.; Hu, B.; Wang, J.; Hu, C.; et al. Clinical Characteristics of COVID-19 Patients with Digestive Symptoms in Hubei, China: A Descriptive, Cross-Sectional, Multicenter Study. Am. J. Gastroenterol. 2020, 115, 766-773. [CrossRef]

171. Vaduganathan, M.; Vardeny, O.; Michel, T.; McMurray, J.J.V.; Pfeffer, M.A.; Solomon, S.D. Renin-Angiotensin-Aldosterone System Inhibitors in Patients with Covid-19. N. Engl. J. Med. 2020, 382, 1653-1659. [CrossRef]

172. Berry, D.J.; Hesketh, K.; Power, C.; Hyppönen, E. Vitamin D status has a linear association with seasonal infections and lung function in British adults. Br. J. Nutr. 2011, 106, 1433-1440. [CrossRef]

173. Derbyshire, E.; Delange, J. COVID-19: Is there a role for immunonutrition, particularly in the over 65s? BMJ Nutr. Prev. Heal. 2020, 3, 100-105. [CrossRef]

174. Kandimalla, R. SARS-CoV-2 pathophysiology and assessment of coronaviruses in CNS diseases with a focus on therapeutic targets. Biochim. Biophys. Acta Mol. Basis Dis. 2020, 1866, 165889. [CrossRef]

175. Atyeo, C.; Slein, M.D.; Fischinger, S.; Burke, J.; Schäfer, A.; Leist, S.R.; Kuzmina, N.A.; Mire, C.; Honko, A.; Johnson, R.; et al. Dissecting strategies to tune the therapeutic potential of SARS-CoV-2-specific monoclonal antibody CR3022. JCI Insight 2021, 6. [CrossRef]

176. Choy, K.T.; Wong, A.Y.; Kaewpreedee, P.; Sia, S.F.; Chen, D.; Hui, K.P.Y.; Chu, D.K.W.; Chan, M.C.W.; Cheung, P.P.; Huang, X. Remdesivir, lopinavir, emetine, and homoharringtonine inhibit SARS-CoV-2 replication in vitro. Antivir. Res. 2020, $178,104786$. [CrossRef] [PubMed]

177. Mantlo, E.; Bukreyeva, N.; Maruyama, J.; Paessler, S.; Huanga, C. Antiviral activities of type I interferons to SARS-CoV-2 infection. Antivir. Res. 2020, 179, 104811. [CrossRef] [PubMed]

178. Tai, W.; Zhang, X.; He, Y.; Jiang, S.; Dua, L. Identification of SARS-CoV RBD-targeting monoclonal antibodies with cross-reactive or neutralizing activity against SARS-CoV-2. Antivir. Res. 2020, 179, 104820. [CrossRef] [PubMed]

179. Jockusch, S.; Tao, C.; Li, X.; Anderson, T.K.; Chien, M.; Kumar, S.; Russo, J.J.; Kirchdoerfer, R.N.; Ju, J. A library of nucleotide analogues terminate RNA synthesis catalyzed by polymerases of coronaviruses that cause SARS and COVID-19. Antivir. Res. 2020, 180, 104857. [CrossRef]

180. Sallard, E.; Lescure, F.-X.; Yazdanpanah, Y.; Mentre, F.; Peiffer-Smadja, N. Type 1 interferons as a potential treatment against COVID-19. Antivir. Res. 2020, 178, 104791. [CrossRef]

181. Jeyaraman, M.; Ranjan, R.; Kumar, R.; Arora, A.; Chaudhary, D.; Ajay, S.S.; Jain, R. Cellular Therapy: Shafts of Light Emerging for COVID-19. Stem Cell Investig. 2020, 7, 11. [CrossRef]

182. Yang, Y.; Islam, M.S.; Wang, J.; Li, Y.; Chen, X. Traditional Chinese Medicine in the Treatment of Patients Infected with 2019-New Coronavirus (SARS-CoV-2): A Review and Perspective. Int. J. Biol. Sci. 2020, 16, 1708-1717. [CrossRef] [PubMed]

183. Fang, L.; Karakiulakis, G.; Roth, M. Antihypertensive drugs and risk of COVID-19? Authors' reply. Lancet Respir. Med. 2020, 8 , e32-e33. [CrossRef]

184. Rahman, N.; Basharat, Z.; Yousuf, M.; Castaldo, G.; Rastrelli, L.; Khan, H. Virtual Screening of Natural Products against Type II Transmembrane Serine Protease (TMPRSS2), the Priming Agent of Coronavirus 2 (SARS-CoV-2). Molecules 2020, $25,2271$. [CrossRef]

185. Oo, A.; Teoh, B.T.; Sam, S.S.; Abu Bakar, S.; Zandi, K. Baicalein and baicalin as Zika virus inhibitors. Arch. Virol. 2019, 164, 585-593. [CrossRef]

186. Gurung, A.B.; Ali, M.A.; Lee, J.; Farah, M.A.; Al-Anazi, K.M. Unravelling lead antiviral phytochemicals for the inhibition of SARS-CoV-2 Mpro enzyme through in silico approach. Life Sci. 2020, 255, 117831. [CrossRef] [PubMed]

187. Gentile, D.; Patamia, V.; Scala, A.; Sciortino, M.T.; Piperno, A.; Rescina, A. Putative Inhibitors of SARS-CoV-2 Main Protease from A Library of Marine Natural Products: A Virtual Screening and Molecular Modeling Study. Mar. Drugs 2020, 18, 225. [CrossRef] [PubMed]

188. Cui, Q.; Huang, C.; Ji, X.; Zhang, W.; Zhang, F.; Wang, L. Possible Inhibitors of ACE2, the Receptor of 2019-nCoV. Preprints. 2020. Available online: https:/ / www.preprints.org/manuscript/202002.0047/v1 (accessed on 14 March 2021).

189. Cheng, J.; Tang, Y.; Bao, B.; Zhang, P. Exploring the Active Compounds of Traditional Mongolian Medicine Agsirga in Intervention of Novel Coronavirus (2019-nCoV) Based on HPLC-Q-Exactive-MS/MS and Molecular Docking Method. ChemRxiv. 2020. Available online: https://chemrxiv.org/articles/preprint/Exploring_the_Active_Compounds_of_Traditional_Mongolian_Medicine_ Agsirga_in_Intervention_of_Novel_Coronavirus_2019-nCoV_Based_on_HPLC-Q-Exactive-MS_MS_and_Molecular_Docking_ Method/11955273/2 (accessed on 14 March 2021).

190. Meneguzzo, F.; Ciriminna, R.; Zabini, F.; Pagliaro, M. Review of Evidence Available on Hesperidin-Rich Products as Potential Tools against COVID-19 and Hydrodynamic Cavitation-Based Extraction as a Method of Increasing Their Production. Processes 2020, 8, 549. [CrossRef] 
191. Pandit, M.; Latha, N. In silico studies reveal potential antiviral activity of phytochemicals from medicinal plants for the treatment of COVID-19 infection. Res. Sq. 2020, 1-10. [CrossRef]

192. Joshi, R.S.; Jagdale, S.S.; Bansode, S.B.; Shankar, S.S.; Tellis, M.B.; Pandya, V.K.; Chugh, A.; Giri, A.P.; Kulkarni, M.J. Discovery of potential multi-target-directed ligands by targeting host-specific SARS-CoV-2 structurally conserved main protease. J. Biomol. Struct. Dyn. 2020, 1-16. [CrossRef] [PubMed]

193. Khaerunnisa, S.; Kurniawan, H.; Awaluddin, R.; Suhartati, S.; Soetjipto, S. Potential Inhibitor of COVID-19 Main Protease (Mpro) From Several Medicinal Plant Compounds by Molecular Docking Study. Preprints. 2020. Available online: https: / / www.preprints.org/manuscript/202003.0226/v1 (accessed on 14 March 2021).

194. Da Silva, J.K.R.; Figueiredo, P.L.B.; Byler, K.G.; Setzer, W.N. Essential Oils as Antiviral Agents, Potential of Essential Oils to Treat SARS-CoV-2 Infection: An In-Silico Investigation. Int. J. Mol. Sci. 2020, 21, 3426. [CrossRef] [PubMed]

195. Zhang, D.-H.; Wu, K.-L.; Zhang, X.; Deng, S.-Q.; Peng, B. In silico screening of Chinese herbal medicines with the potential to directly inhibit 2019 novel coronavirus. J. Integr. Med. 2020, 18, 152-158. [CrossRef]

196. Qamar, M.T.U.; Alqahtani, S.M.; Alamri, M.A.; Chen, L.-L. Structural basis of SARS-CoV-2 3CLpro and anti-COVID-19 drug discovery from medicinal plants. J. Pharm. Anal. 2020, 10, 313-319. [CrossRef] [PubMed]

197. Olubiyi, O.O.; Olagunju, M.; Keutmann, M.; Strodel, B. High Throughput Virtual Screening to Discover Inhibitors of the Main Protease of the Coronavirus SARS-CoV-2. Preprints. 2020. Available online: https:/ /www.preprints.org/manuscript/202004.016 1/v2 (accessed on 14 March 2021).

198. Chen, C.N.; Lin, C.P.C.; Huang, K.K.; Chen, W.C.; Hsieh, H.P.; Liang, P.H.; Hsu, J.T.A. Inhibition of SARS-CoV 3C-like protease activity by Theaflavin-3,30-digallate (TF3). Evid. Based Complementary Altern. Med. 2005, 2, 209-215. [CrossRef]

199. El Fiky, A.A. Natural products may interfere with SARS-CoV-2 attachment to the host cell. J. Biomol. Struct. Dyn. 2020, 1-10. [CrossRef]

200. Sharma, A.; Tiwari, V.; Sowdhamini, R. Computational search for potential COVID-19 drugs from FDA-approved drugs and small molecules of natural origin identifies several anti-virals and plant products. J. Biosci. 2020, 45, 1-18. [CrossRef]

201. Gretebeck, L.M.; Subbarao, K. Animal models for SARS and MERS coronaviruses. Curr. Opin. Virol. 2015, 13, 123-129. [CrossRef]

202. Cockrell, A.S.; Peck, K.M.; Yount, B.L.; Agnihothram, S.S.; Scobey, T.; Curnes, N.R.; Baric, R.S.; Heise, M.T. Mouse Dipeptidyl Peptidase 4 Is Not a Functional Receptor for Middle East Respiratory Syndrome Coronavirus Infection. J. Virol. 2014, 88, 5195-5199. [CrossRef]

203. Nagata, N.; Iwata, N.; Hasegawa, H.; Fukushi, S.; Yokoyama, M.; Harashima, A.; Sato, Y.; Saijo, M.; Morikawa, S.; Sata, T. Participation of both Host and Virus Factors in Induction of Severe Acute Respiratory Syndrome (SARS) in F344 Rats Infected with SARS Coronavirus. J. Virol. 2006, 81, 1848-1857. [CrossRef]

204. Roychoudhury, S.; Das, A.; Sengupta, P.; Dutta, S.; Roychoudhury, S.; Choudhury, A.P.; Ahmed, A.B.F.; Bhattacharjee, S.; Slama, P. Viral Pandemics of the Last Four Decades: Pathophysiology, Health Impacts and Perspectives. In Int. J. Environ. Res. Public Health; 2020; Volume 17, p. 9411.

205. Roychoudhury, S.; Das, A.; Jha, N.K.; Kesari, K.K.; Roychoudhury, S.; Jha, S.K.; Kosgi, R.; Choudhury, A.P.; Lukac, N.; Madhu, N.R.; et al. Viral pathogenesis of SARS-CoV-2 infection and male reproductive health. Open Biol. 2021, 11, 200347.

206. Roychoudhury, S.; Das, A.; Sengupta, P.; Dutta, S.; Roychoudhury, S.; Kolesarova, A.; Hleba, L.; Massanyi, P.; Slama, P. Viral pandemics of twenty-first century. J. Microbiol. Biotech. Food Sci. 2021, 10, 711-716.

207. Jha, N.K.; Ojha, S.; Jha, S.K.; Dureja, H.; Singh, S.K.; Shukla, S.D.; Chellappan, D.K.; Gupta, G.; Bhardwaj, S.; Kumar, N.; et al. Evidence of Coronavirus (CoV) Pathogenesis and Emerging Pathogen SARS-CoV-2 in the Nervous System: A Review on Neurological Impairments and Manifestations. J Mol Neurosci. 2021, 19, 1-18.

208. Javed, H.; Meeran, M.F.N.; Jha, N.K.; Ojha, S. Carvacrol, a Plant Metabolite Targeting Viral Protease (M pro $)$ and ACE2 in Host Cells Can Be a Possible Candidate for COVID-19. Front Plant Sci. 2021, 11, 601335. [CrossRef] [PubMed]

209. Jeyaraman, M.; John, A.; Koshy, S.; Ranjan, R.; Anudeep, T.C.; Jain, R.; Swati, K.; Jha, N.K.; Sharma, A.; Kesari, K.K.; et al. Fostering mesenchymal stem cell therapy to halt cytokine storm in COVID-19. Biochim Biophys Acta MolBasis Dis. 2021, 1867, 166014. [CrossRef] [PubMed]

210. Nagoor Meeran, M.F.; Javed, H.; Sharma, C.; Goyal, S.N.; Kumar, S.; Jha, N.K.; Ojha, S. Can Echinacea be a potential candidate to target immunity, inflammation, and infection-The trinity of coronavirus disease 2019. Heliyon. 2021, 7, e05990. [CrossRef] [PubMed] 